\title{
Ceramic Hosts for Fission Products Immobilization
}

\author{
Peter C. Kong
}

July 2010

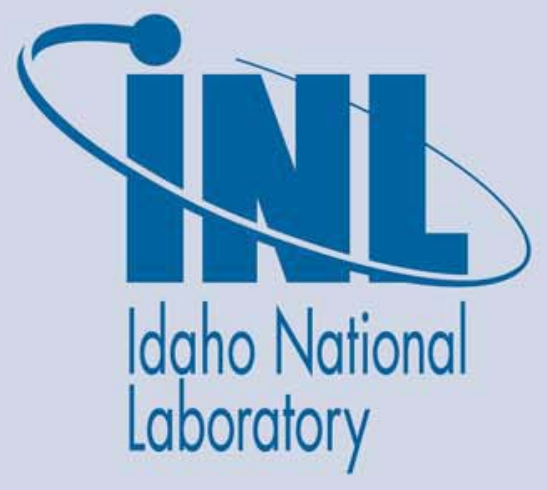

The INL is a U.S. Department of Energy National Laboratory operated by Battelle Energy Alliance 
INL/EXT-10-19429

FCRD-Waste 2010-3000115

\title{
Ceramic Hosts for Fission Products Immobilization
}

\author{
Peter C. Kong
}

July 2010

\section{Idaho National Laboratory \\ Fuel Cycle Research \& Development \\ Idaho Falls, Idaho 83415}

http://www.inl.gov

Prepared for the

U.S. Department of Energy

Office of Nuclear Energy

Under DOE Idaho Operations Office

Contract DE-AC07-05ID14517 


\section{DISCLAIMER}

This information was prepared as an account of work sponsored by an agency of the U.S. Government. Neither the U.S. Government nor any agency thereof, nor any of their employees, makes any warranty,

expressed or implied, or assumes any legal liability or responsibility for the accuracy, completeness, or usefulness, of any information, apparatus, product, or process disclosed, or represents that its use would not infringe privately owned rights. References herein to any specific commercial product, process, or service by trade name, trade mark, manufacturer, or otherwise, does not necessarily constitute or imply its endorsement, recommendation, or favoring by the U.S. Government or any agency thereof. The views and opinions of authors expressed herein do not necessarily state or reflect those of the U.S. Government or any agency thereof. 


\section{SUMMARY}

Several crystalline hosts were synthesized and proposed for fission products immobilization. A recent FY-10 study concentrated on strontium substitution into spinels $\left(\mathrm{MgAl}_{2} \mathrm{O}_{4}\right)$, perovskite $\left(\mathrm{CaTiO}_{3}\right)$, and zirconolite $\left(\mathrm{CaZrTi}_{2} \mathrm{O}_{7}\right)$. Strontium cannot substitute into $\mathrm{Mg}^{2+}$ sites in the spinel structure because the $\mathrm{Sr}^{2+}$ ion is much larger than the $\mathrm{Mg}^{2+}$ ions. This research found that $\mathrm{CaAl}_{2} \mathrm{O}_{4}$ is a suitable alternative for $\mathrm{Sr}$ immobilization because $\mathrm{Sr}^{2+}$ is only $14 \%$ larger than $\mathrm{Ca}^{2+}$. Both $\mathrm{CaAl}_{2} \mathrm{O}_{4}$ and $\mathrm{SrAl}_{2} \mathrm{O}_{4}$ have identical crystalline structure and their unit cell dimensions are quite similar to each other. Both systems also have higher members that are analogue to each other and their crystalline structures are identical. A single phase of $\mathrm{Ca}_{0.5} \mathrm{Sr}_{0.5} \mathrm{Al}_{2} \mathrm{O}_{4}$ may have been synthesized and more analysis of this material is necessary to confirm the composition. The $\mathrm{CaTiO}_{3}$ and $\mathrm{SrTiO}_{3}$ have been successfully synthesized as a single phase product. $\mathrm{CaZrTi}_{2} \mathrm{O}_{7}$ was also successfully synthesized. However, $\mathrm{SrZrTi}_{2} \mathrm{O}_{7}$ and $\mathrm{Ca}_{0.5} \mathrm{Sr}_{0.5} \mathrm{ZrTi}_{2} \mathrm{O}_{7}$ have not been successfully synthesized yet. Higher temperature synthesis work will need to continue for these compositions. 
Ceramic Hosts for Fission Products Immobilization 


\section{CONTENTS}

SUMMARY iii

ACRONYMS vii

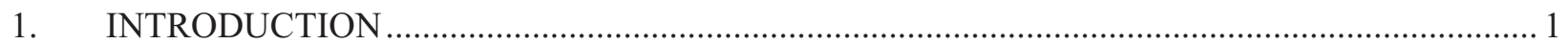

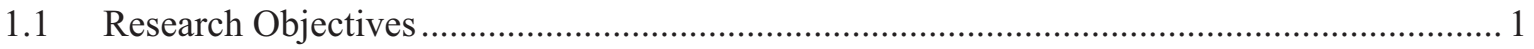

1.2 Scope of Research for Synthesis of Fission Product Crystalline Hosts .................................. 1

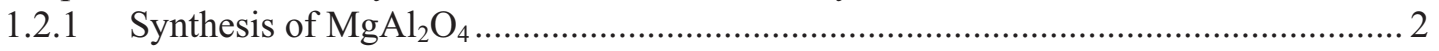

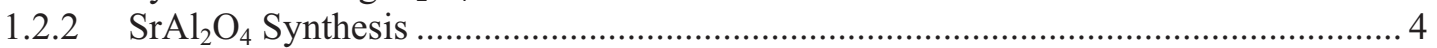

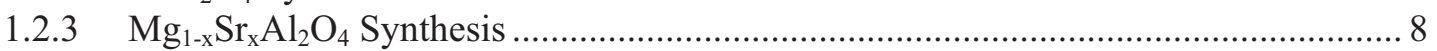

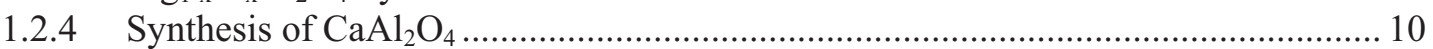

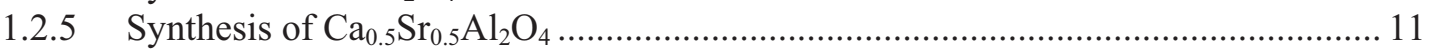

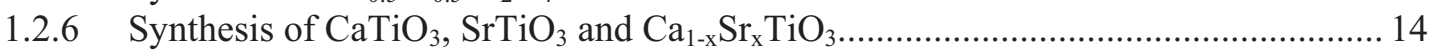

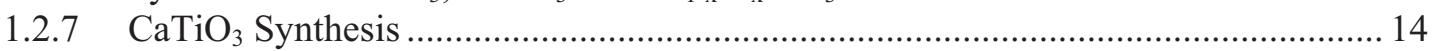

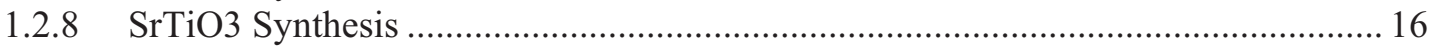

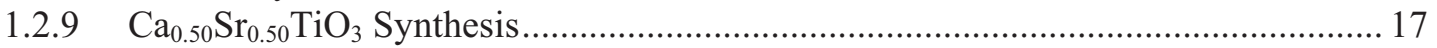

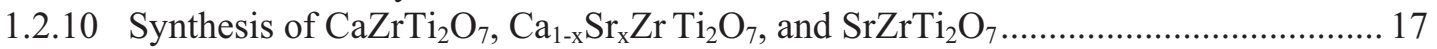

1.2.11 Second Synthesis of $\mathrm{CaZrTi}_{2} \mathrm{O}_{7}, \mathrm{Ca}_{0.5} \mathrm{Sr}_{0.5} \mathrm{Zr} \mathrm{Ti}_{2} \mathrm{O}_{7}$, and $\mathrm{SrZrTi}_{2} \mathrm{O}_{7} \ldots \ldots \ldots \ldots \ldots \ldots \ldots . . . . . . . . .18$

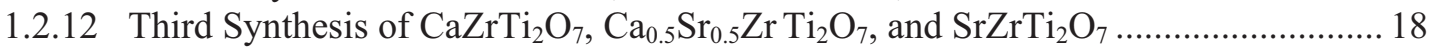

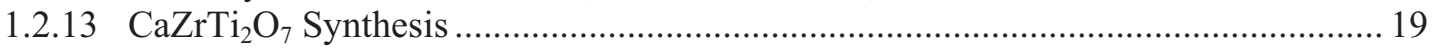

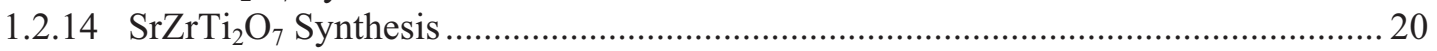

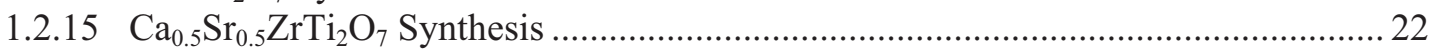

1.2.16 Synthesis of Lanthanide Substituted Crystalline Hosts............................................. 24

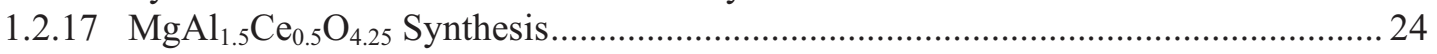

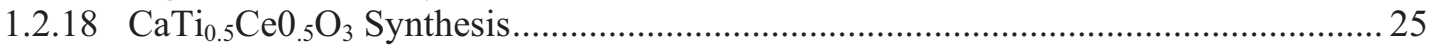

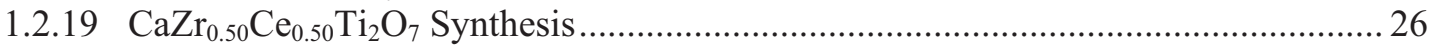

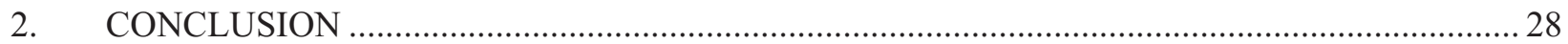

\section{FIGURES}

Figure 1. A mixed oxide disc is heated by a plasma jet for solid state synthesis.Error! Bookmark not defined. Figure 2. XRD analysis of the front side of the plasma-synthesized disc for $\mathrm{MgAl}_{2} \mathrm{O}_{4}$.Error! Bookmark not defined. Figure 3. XRD analysis of the front side of the plasma-synthesized disc... Error! Bookmark not defined. Figure 4. XRD analysis of the back side of the plasma-synthesized disc... Error! Bookmark not defined. Figure 5. XRD analysis of the front side of the heat-treated plasma-synthesized disc.Error! Bookmark not defined. Figure 6. XRD analysis of the back side of the heat-treated plasma-synthesized disc.Error! Bookmark not defined. Figure 7. XRD analysis of the plasma disc after 12 hours of heat treatment at $1350^{\circ} \mathrm{C}$.Error! Bookmark not defined. Figure 8. XRD analysis of $0.75 \mathrm{MgO}+0.25 \mathrm{SrO}+\mathrm{Al}_{2} \mathrm{O}_{3} \rightarrow \mathrm{Mg}_{0.75} \mathrm{Sr}_{0.25} \mathrm{Al}_{2} \mathrm{O}_{4}$ reaction.Error! Bookmark not defined. Figure 9. XRD analysis of $0.5 \mathrm{MgO}+0.5 \mathrm{SrO}+\mathrm{Al}_{2} \mathrm{O}_{3} \rightarrow \mathrm{Mg}_{0.5} \mathrm{Sr}_{0.5} \mathrm{Al}_{2} \mathrm{O}_{4}$ reaction.Error! Bookmark not defined. Figure 10. XRD analysis of $0.25 \mathrm{MgO}+0.75 \mathrm{SrO}+\mathrm{Al}_{2} \mathrm{O}_{3} \rightarrow \mathrm{Mg}_{0.25} \mathrm{Sr}_{0.75} \mathrm{Al}_{2} \mathrm{O}_{4}$ reaction.Error! Bookmark not defined. Figure 11. XRD analysis of plasma-synthesized $\mathrm{CaAl}_{2} \mathrm{O}_{4}$ from mixed nitrate solutions.Error! Bookmark not defined. 
Figure 12. XRD analysis of heat-treated plasma-synthesized $\mathrm{CaAl}_{2} \mathrm{O}_{4}$ powder.Error! Bookmark not defined.

Figure 13. XRD analysis shows the $0.5 \mathrm{CaO}+0.5 \mathrm{SrO}+\mathrm{Al}_{2} \mathrm{O}_{3}$ reaction product.Error! Bookmark not defined.

Figure 14a. SEM micrograph shows the morphology of the sintered particles for the 86 hours $1350^{\circ} \mathrm{C}$ reaction product. Error! Bookmark not defined.

Figure 14b. SEM analysis of $\mathrm{Ca}_{0.5} \mathrm{Sr}_{0.5} \mathrm{Al}_{2} \mathrm{O}_{4}$ product synthesized at $1350^{\circ} \mathrm{C}$ for 86 hours.Error! Bookmark not defined.

Figure 15a. EDX analysis on white spot 1 in Figure 14b. Error! Bookmark not defined.

Figure 15b. EDX analysis on black spot 1 in Figure 14b. Error! Bookmark not defined.

Figure 16a. XRD analysis of $\mathrm{CaO}+\mathrm{TiO}_{2}$ reaction product produced at $1350^{\circ} \mathrm{C}$.Error! Bookmark not defined.

Figure 16b. XRD analysis of $\mathrm{CaO}+\mathrm{TiO} 2$ reaction product reacted at $1650^{\circ} \mathrm{C}$.Error! Bookmark not defined.

Figure 17a. XRD analysis of $\mathrm{SrO}+\mathrm{TiO}_{2}$ reaction at $1350^{\circ} \mathrm{C}$. Error! Bookmark not defined.

Figure $17 \mathrm{~b}$. XRD analysis of $\mathrm{SrO}+\mathrm{TiO}_{2}$ reaction at $1650^{\circ} \mathrm{C}$ Error! Bookmark not defined.

Figure 18. The appearance of $\mathrm{CaTiO}_{3}, \mathrm{SrTiO}_{3}, \mathrm{CaZrTi}_{2} \mathrm{O}_{7}$, and $\mathrm{SrZrTi}_{2} \mathrm{O}_{7}$ product powders after 13 hours of high-temperature reaction. Error! Bookmark not defined.

Figure 19. XRD result of the product after the 16 hours at $1350^{\circ} \mathrm{C}$ Error! Bookmark not defined.

Figure 20. XRD result of the product after the 64 hours reaction at $1450^{\circ} \mathrm{C}$.Error! Bookmark not defined.

Figure 21. XRD result of the product after another 39 hours of reaction at $1500^{\circ} \mathrm{C}$.Error! Bookmark not defined.

Figure 22. XRD result of the product after the 16 hours reaction at $1350^{\circ} \mathrm{C}$ and 64 hours at $1450^{\circ} \mathrm{C}$ (pink trace). XRD result of the product after additional 39 hours of reaction at $1500^{\circ} \mathrm{C}$ (black trace).

Error! Bookmark not defined.

Figure 23. XRD result of the product after additional 39 hours of reaction at $1650^{\circ} \mathrm{C}$.Error! Bookmark not defined.

Figure 24. XRD result of the product after the 16 hours initial reaction at $1350^{\circ} \mathrm{C}$ and 64 hours soaking at $1450^{\circ} \mathrm{C}$ (purple trace). XRD result of the product after additional 39 hours of reaction at $1500^{\circ} \mathrm{C}$ (black trace).

Error! Bookmark not defined.

Figure 25. XRD result of the product after additional 39 hours of reaction at $1650^{\circ} \mathrm{C}$.Error! Bookmark not defined. Figure 26. XRD analysis of the $\mathrm{MgO}+0.75 \mathrm{Al}_{2} \mathrm{O}_{3}+0.5 \mathrm{CeO}_{2}$ reaction product.Error! Bookmark not defined.

Figure 27. XRD analysis of the $0.5 \mathrm{CaO}+0.5 \mathrm{CeO}_{2}+\mathrm{TiO}_{2}$ reaction product.Error! Bookmark not defined.

Figure 28. XRD analysis of the $\mathrm{CaO}+0.5 \mathrm{ZrO}_{2}+0.5 \mathrm{CeO}_{2}+2 \mathrm{TiO}_{2}$ reaction product.Error! Bookmark not defined.

\section{TABLES}

Table 1. Crystalline aluminate and titanate hosts suitable for immobilization 


\section{ACRONYMS}

$\begin{array}{ll}\text { BCC } & \text { body centered cubic } \\ \text { EDX } & \text { energy dispersive } x \text {-ray } \\ \text { FCC } & \text { face centered cubic } \\ \text { PCT } & \text { product consistency test } \\ \text { SEM } & \text { scanning electron microscopy } \\ \text { TRU } & \text { transuranic } \\ \text { XRD } & \text { x-ray diffraction }\end{array}$


Ceramic Hosts for Fission Products Immobilization 


\section{CERAMIC HOSTS FOR FISSION PRODUCTS IMMOBILIZATION}

\section{INTRODUCTION}

Natural spinel, perovskite, and zirconolite rank among the most leach resistant of mineral forms. They also have a strong affinity for a large number of other elements, including actinides. Specimens of natural perovskite and zirconolite were radioisotope dated and found to have survived at least two billion years of natural processes while still retaining their loading of uranium and thorium ${ }^{\mathrm{a}}$. Developers of the Synroc waste form recognized and exploited the capability of these minerals to securely immobilize transuranic (TRU) elements in high-level waste ${ }^{b}$. However, the Synroc process requires a relatively uniform input and hot pressing equipment to produce the waste form. It is desirable to develop alternative approaches to fabricate these durable waste forms to immobilize the radioactive elements. One approach is using a hightemperature process to synthesize these mineral host phases to incorporate the fission products in their crystalline structures. These mineral assemblages with immobilized fission products are then isolated in a durable high-temperature glass for periods measured on a geologic time scale.

This is a long-term research concept and will begin with the laboratory synthesis of the pure spinel $\left(\mathrm{MgAl}_{2} \mathrm{O}_{4}\right)$, perovskite $\left(\mathrm{CaTiO}_{3}\right)$, and zirconolite $\left(\mathrm{CaZrTi}_{2} \mathrm{O}_{7}\right)$ from their constituent oxides. Hightemperature furnace and/or thermal plasma will be used for the synthesis of these ceramic host phases. Regular strontium oxide will be doped into these ceramic phases to investigate the development of substitution phases such as $\mathrm{Mg}_{1-\mathrm{x}} \mathrm{Sr}_{\mathrm{x}} \mathrm{Al}_{2} \mathrm{O}_{4}, \mathrm{Ca}_{1-\mathrm{x}} \mathrm{Sr}_{\mathrm{x}} \mathrm{TiO}_{3}$, and $\mathrm{Ca}_{1-\mathrm{x}} \mathrm{Sr}_{\mathrm{x}} \mathrm{ZrTi}_{2} \mathrm{O}_{7}$. X-ray diffraction (XRD) will be used to establish the crystalline structures of the pure ceramic hosts and the substitution phases. Scanning electron microscopy (SEM) and energy dispersive X-ray analysis (EDX) will be performed for product morphology and strontium distribution in the crystalline hosts. The range of strontium doping will reach the full substitution of the $\mathrm{Mg}$ and $\mathrm{Ca}$ in the ceramic host phases.

The immobilization of rare earth (lanthanides) fission products in these ceramic host phases will also be studied this year. Cerium oxide was chosen to represent the rare earth fission product for substitution studies in spinel, perovskite, and zirconolite ceramic hosts. Cerium has +3 and +4 oxidation states and it can replace some of the trivalent or tetravalent host ions to produce the substitution ceramics, such as $\mathrm{MgAl}_{2-\mathrm{x}} \mathrm{Ce}_{\mathrm{x}} \mathrm{O}_{4}, \mathrm{CaTi}_{1-\mathrm{x}} \mathrm{Ce}_{\mathrm{x}} \mathrm{O}_{3}, \mathrm{CaZr}_{1-\mathrm{x}} \mathrm{Ce}_{\mathrm{x}} \mathrm{Ti}_{2} \mathrm{O}_{7}$, and $\mathrm{CaZrTi}_{2-\mathrm{x}} \mathrm{Ce}_{\mathrm{x}} \mathrm{O}_{7}$. XRD analysis will be used to compare the crystalline structures of the pure ceramic hosts and the substitution phases. SEM-EDX analysis will be used to study the Ce distribution in the ceramic host phases. The range of cerium doping will reach the full substitution of the trivalent or tetravalent ions, $\mathrm{Al}, \mathrm{Ti}$, and $\mathrm{Zr}$, in the ceramic host phases.

\subsection{Research Objectives}

This phase of the study will establish the scientific ground work for the ceramic hosts to incorporate the fission products into their structures. Other fission products substitution into the ceramic hosts will be continued in out years. The design of a durable glass phase to isolate these fission products loaded ceramic hosts will be studied in out years. A product consistency test (PCT) will be performed on these waste forms after this part of the research is completed.

\subsection{Scope of Research for Synthesis of Fission Product Crystalline Hosts}

- $\quad$ Synthesis of $\mathrm{MgAl}_{2} \mathrm{O}_{4}, \mathrm{CaTiO}_{3}$, and $\mathrm{CaZrTi}_{2} \mathrm{O}_{7}$

a. A. E. Ringwood et.al., Immobilization of high level nuclear reactor waste in SYNROC, Nature, 278:219-223, 1979.

b. A. E. Ringwood et.al., SYNROC, Radioactive Waste Forms for the Future, p233, Lutze and Ewing edited, 1988. 
- Synthesis of $\mathrm{Sr}$-doped $\mathrm{Mg}_{1-\mathrm{x}} \mathrm{Sr}_{\mathrm{x}} \mathrm{Al}_{2} \mathrm{O}_{4}, \mathrm{Ca}_{1-\mathrm{x}} \mathrm{Sr}_{\mathrm{x}} \mathrm{TiO}_{3}$ and $\mathrm{Ca}_{1-\mathrm{x}} \mathrm{Sr}_{\mathrm{x}} \mathrm{ZrTi}_{2} \mathrm{O}_{7}$ until reaching compositions of $\mathrm{SrAl}_{2} \mathrm{O}_{4}, \mathrm{SrTiO}_{3}$, and $\mathrm{SrZrTi}_{2} \mathrm{O}_{7}$

- Synthesis of Ce-doped $\mathrm{MgAl}_{2-\mathrm{x}} \mathrm{Ce}_{\mathrm{x}} \mathrm{O}_{4}, \mathrm{CaTi}_{1-\mathrm{x}} \mathrm{Ce}_{\mathrm{x}} \mathrm{O}_{3}, \mathrm{CaZr}_{1-\mathrm{x}} \mathrm{Ce}_{\mathrm{x}} \mathrm{Ti}_{2} \mathrm{O}_{7}$ and $\mathrm{CaZrTi}_{2-\mathrm{x}} \mathrm{Ce}_{\mathrm{x}} \mathrm{O}_{7}$ until reaching compositions of $\mathrm{MgCeO}_{3}, \mathrm{CaCeO}_{3}, \mathrm{CaCeTi}_{2} \mathrm{O}_{7}, \mathrm{CaZrTiCeO}_{7}$, and $\mathrm{CaZrCe}_{2} \mathrm{O}_{7}$

- Material characterizations-XRD, SEM, and EDX analysis - of these ceramics.

Scope of FY-10 work will synthesize some selected crystalline hosts. Some of the fully substituted compounds may not be previously known, making comparison between the crystalline structures of the new compounds with reference standards difficult. This research will provide the opportunity to investigate their existence and their potential as ceramic hosts to immobilize the fission products.

The project was selected in mid-November, the work package was submitted in December, and experimental preparations began in mid-December. A description of the experimental work was submitted to the laboratory manager and the ES\&H team in December 2009 for approval. Starting oxides $\mathrm{MgO}, \mathrm{Al}_{2} \mathrm{O}_{3}, \mathrm{CaO}, \mathrm{TiO}_{2}, \mathrm{ZrO}_{2}, \mathrm{SrO}$, and $\mathrm{CeO}_{2}$ were gathered for experiments.

\subsubsection{Synthesis of $\mathrm{MgAl}_{2} \mathrm{O}_{4}$}

XRD analyses for the constituent oxides $\left(\mathrm{MgO}, \mathrm{Al}_{2} \mathrm{O}_{3}, \mathrm{CaO}, \mathrm{TiO}_{2}, \mathrm{ZrO}_{2}, \mathrm{SrO}\right.$, and $\left.\mathrm{CeO}_{2}\right)$ were completed prior to the synthesis of the compound oxides. The synthesis of $\mathrm{MgAl}_{2} \mathrm{O}_{4}, \mathrm{SrAl}_{2} \mathrm{O}_{4}, \mathrm{Mg}_{0.75} \mathrm{SrO}_{0.25} \mathrm{Al}_{2} \mathrm{O}_{4}$, $\mathrm{Mg}_{0.5} \mathrm{SrO}_{0.5} \mathrm{Al}_{2} \mathrm{O}_{4}$, and $\mathrm{Mg}_{0.25} \mathrm{SrO}_{0.75} \mathrm{Al}_{2} \mathrm{O}_{4}$ began in January 2010. The substitution reactions are listed below. It begins with $\mathrm{MgAl}_{2} \mathrm{O}_{4}$ and progresses to $\mathrm{SrAl}_{2} \mathrm{O}_{4}$ through systemic substitution of $\mathrm{MgO}$ by $\mathrm{SrO}$ :

$\mathrm{MgO}+\mathrm{Al}_{2} \mathrm{O}_{3} \rightarrow \mathrm{MgAl}_{2} \mathrm{O}_{4}$

$0.75 \mathrm{MgO}+0.25 \mathrm{SrO}+\mathrm{Al}_{2} \mathrm{O}_{3} \rightarrow \mathrm{Mg}_{0.75} \mathrm{Sr}_{0.5} \mathrm{Al}_{2} \mathrm{O}_{4}$

$0.5 \mathrm{MgO}+0.5 \mathrm{SrO}+\mathrm{Al}_{2} \mathrm{O}_{3} \rightarrow \mathrm{M}_{\mathrm{g} 0.5} \mathrm{Sr}_{0.5} \mathrm{Al}_{2} \mathrm{O}_{4}$

$0.25 \mathrm{MgO}+0.75 \mathrm{SrO}+\mathrm{Al}_{2} \mathrm{O}_{3} \rightarrow \mathrm{Mg}_{0.25} \mathrm{Sr}_{0.75} \mathrm{Al}_{2} \mathrm{O}_{4}$

$\mathrm{SrO}+\mathrm{Al}_{2} \mathrm{O}_{3} \rightarrow \mathrm{SrAl}_{2} \mathrm{O}_{4}$

$\mathrm{MgAl}_{2} \mathrm{O}_{4}$ and $\mathrm{SrAl}_{2} \mathrm{O}_{4}$ were the first two compounds to be synthesized using thermal plasma heating to induce a solid state reaction between the constituent oxides. Thermal plasma can produce very high temperatures and heat materials much faster than a conventional furnace. The thermal plasma-assisted solid state reaction is shown in Figure 1. The oxides were well mixed, pressed into a disc, and loaded into a graphite holder. The disc was subjected to thermal plasma heating for a short period of time. The starting oxides all have melting temperatures higher than $2000^{\circ} \mathrm{C}$ and even with plasma heating, the sample did not melt in the experiment. It indicated the reaction temperature did not reach $2072^{\circ} \mathrm{C}$, the melting temperature of alumina and the lowest among all the starting oxides. After cooling,

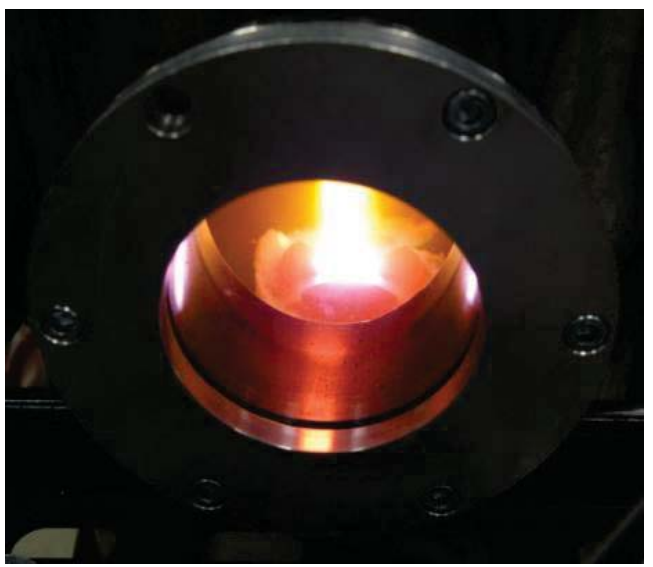

Figure 1. A mixed oxide disc is heated by a plasma jet for solid state synthesis. the disc was removed and XRD was performed on both sides of the sample to reveal the degree of reaction. XRD on the plasma-facing side of the disc showed the reaction was not complete and a significant amount of the starting oxides still remained. However, $\mathrm{MgAl}_{2} \mathrm{O}_{4}$ spinel and a face centered cubic (FCC) solid solution of $\mathrm{Mg}_{0.388} \mathrm{Al}_{2.408} \mathrm{O}_{4}$ were observed in the product. XRD on the back side of the disc showed no reaction at all and the starting oxides remained. This implied that the temperature on the back side of the disc was significantly lower and could not initiate the reaction during heating. 
A second heating was carried out on the sample disc; a thermal couple was incorporated into the graphite holder and touched the back side of the sample. The temperature registered $1045^{\circ} \mathrm{C}$ on the back side of the disc during plasma heating. The disc was about $0.25 \mathrm{in}$. thick and the temperature on the front side should be higher. The reaction temperature was below $40 \%$ melting of $\mathrm{MgO}$ and about $50 \%$ of $\mathrm{Al}_{2} \mathrm{O}_{3}$. At this temperature, the reaction rate between these two oxides would be very slow and require a much longer heating time to react appreciably. XRD on both sides of the disc revealed $\mathrm{MgAl}_{2} \mathrm{O}_{4}$ and $\mathrm{Mg}_{0.388} \mathrm{Al}_{2.408} \mathrm{O}_{4}$ formation. However, the starting oxides remained prominent in the disc. In order to accomplish a complete reaction, the plasma temperature must be increased. The $\mathrm{MgAl}_{2} \mathrm{O}_{4}$ disc broke after the second XRD analysis. Since the reaction temperature was low, the majority of the constituent oxides did not react, and the disc showed no strength. Another plasma heating was carried with the broken disc and 3\% air was added to the plasma to improve its reactivity. Oxygen and nitrogen molecules dissociated into atoms in the upper part of the plasma and the atoms recombined downstream as the plasma gas cooled. The disc surface provided excellent sites for gas particles' recombination. Gas particles' recombination releases energy, and should transfer the energy as heat to the disc and heat the material to higher temperatures. However, the thermocouple on the back side of the disc registered a temperature of $923^{\circ} \mathrm{C}$. This temperature was slightly lower than the temperature registered during the second plasma heating when no air was added. It is possible that the position of the sample holder was not identical to the previous run. The air added to the plasma gas acted as a heat sink to lower the heat content of the plasma. XRD on both sides of the third plasma-heated disc showed $\mathrm{MgAl}_{2} \mathrm{O}_{4}$ formation, while the front side showed more $\mathrm{MgAl}_{2} \mathrm{O}_{4}$ formation than the back side. However, the FCC solid solution of $\mathrm{Mg}_{0.388} \mathrm{Al}_{2.408} \mathrm{O}_{4}$ still remained present.

The $\mathrm{MgAl}_{2} \mathrm{O}_{4}$ synthesis was repeated with a new $\mathrm{MgO}$ and $\mathrm{Al}_{2} \mathrm{O}_{3}$ disc. The standoff distances of the sample holder to the plasma jet was calibrated. The calibrated standoff distances should give a more repeatable temperature history of the heating process, and the effect of plasma reactivity to $\mathrm{MgAl}_{2} \mathrm{O}_{4}$ synthesis should be revealed. A high-temperature thermocouple was incorporated into the sample holder, in contact with the top side of the sample disc. The thermocouple was shielded from the plasma by the sample holder lid. The temperature on the back side of the disc was also monitored by a second thermocouple. The temperature recorded during plasma heating was $1240^{\circ} \mathrm{C}$ on the front side, while the back side was slightly above $900^{\circ} \mathrm{C}$. XRD showed some reaction between $\mathrm{MgO}$ and $\mathrm{Al}_{2} \mathrm{O}_{3}$ to form $\mathrm{MgAl}_{2} \mathrm{O}_{4}$ on the plasma facing side. Figure 2 shows the XRD analysis on the front side of the plasma disc. The analysis showed that some $\mathrm{Mg}_{0.388} \mathrm{Al}_{2.408} \mathrm{O}_{4}$ and $\mathrm{MgAl}_{2} \mathrm{O}_{4}$ formed in the reaction. A majority of $\mathrm{MgO}$ and a small amount of $\mathrm{Al}_{2} \mathrm{O}_{3}$ did not react. However, on the back side of the disc, XRD analysis showed no reaction between the $\mathrm{MgO}$ and $\mathrm{Al}_{2} \mathrm{O}_{3}$. The temperature of the process was not high enough for the reaction to proceed at a high rate. 


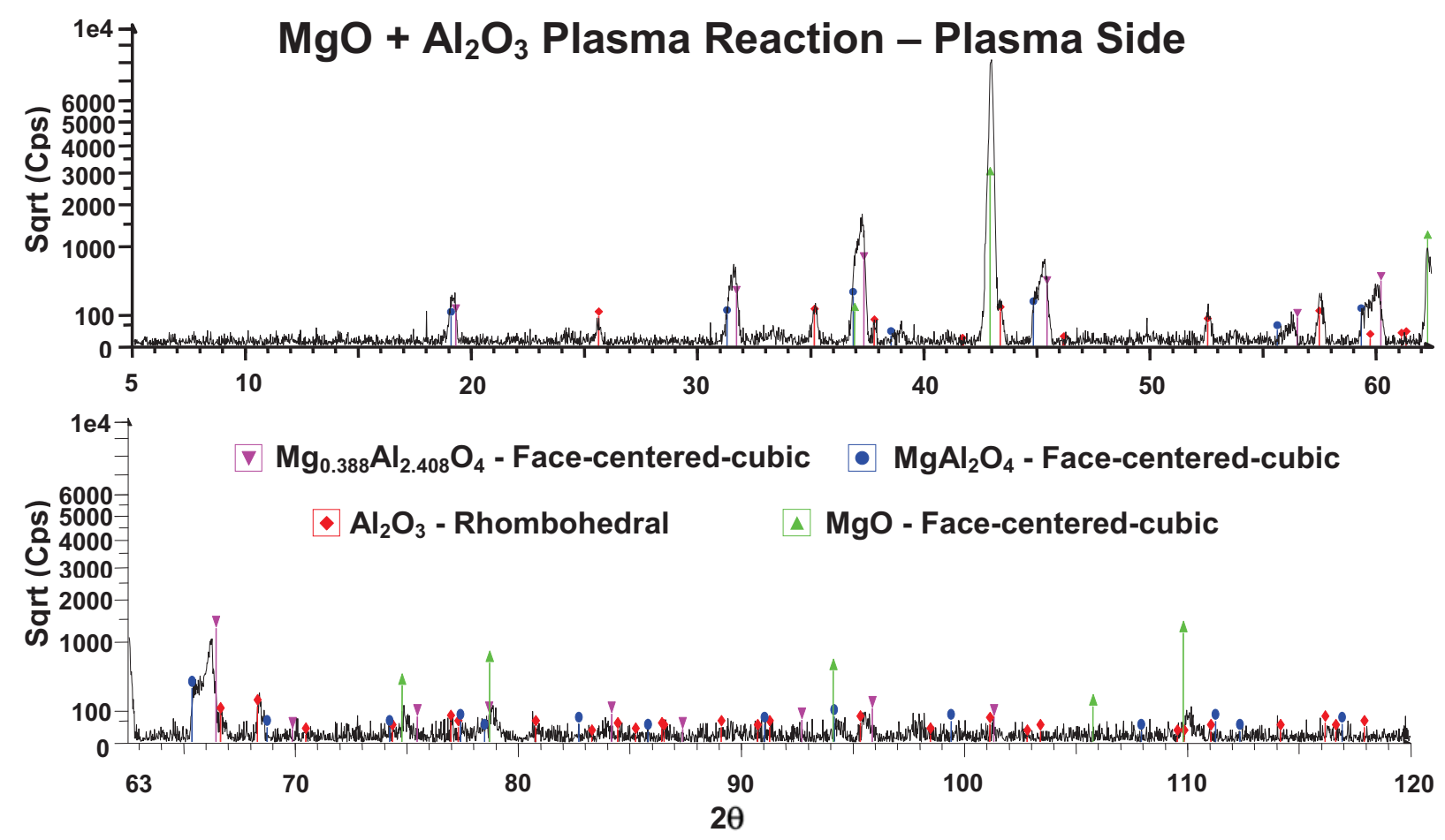

Figure 2. XRD analysis of the front side of the plasma-synthesized disc for $\mathrm{MgAl}_{2} \mathrm{O}_{4}$.

\subsection{2 $\mathrm{SrAl}_{2} \mathrm{O}_{4}$ Synthesis}

The result of plasma synthesis of $\mathrm{SrAl}_{2} \mathrm{O}_{4}$ from $\mathrm{SrO}$ and $\mathrm{Al}_{2} \mathrm{O}_{3}$ was completely different. XRD of the $\mathrm{SrO}$ and $\mathrm{Al}_{2} \mathrm{O}_{3}$ plasma reaction product revealed that the constituent oxides had reacted significantly on both sides of the disc at plasma temperatures comparable to the $\mathrm{MgAl}_{2} \mathrm{O}_{4}$ reaction. The starting oxides were almost completely reacted after 10 minutes of plasma heating. The reaction between constituent oxides was complete on the front side of the sample while the back side showed only a residual amount of the starting aluminum and strontium oxides. Strontium is below $\mathrm{Ca}$ in the periodic table and its reactivity is much higher than $\mathrm{Mg}$. The higher reactivity of strontium significantly enhances the reaction between the starting powders. Several strontium aluminate phases, $\mathrm{Sr}_{3} \mathrm{Al}_{2} \mathrm{O}_{6}, \mathrm{Sr}_{12} \mathrm{Al}_{14} \mathrm{O}_{33}$, and $\mathrm{SrAl}_{2} \mathrm{O}_{4}$, were identified by XRD with $\mathrm{SrAl}_{2} \mathrm{O}_{4}$ being the major phase. The plasma-heated side of the disc showed two crystalline phases, a monoclinic $\mathrm{SrAl}_{2} \mathrm{O}_{4}$, and a simple cubic $\mathrm{Sr}_{3} \mathrm{Al}_{2} \mathrm{O}_{6}$ (or $2 \mathrm{SrO} \bullet \mathrm{SrAl}_{2} \mathrm{O}_{4}$ ). Figure 3 shows the result of XRD analysis on the front side of the plasma-synthesized disc. All starting oxides reacted on this side. The back side of the disc showed three crystalline phases, the monoclinic $\mathrm{SrAl}_{2} \mathrm{O}_{4}$, the simple cubic $\mathrm{Sr}_{3} \mathrm{Al}_{2} \mathrm{O}_{6}$ (or $2 \mathrm{SrO} \bullet \mathrm{SrAl}_{2} \mathrm{O}_{4}$ ), and a body centered cubic (BCC) $\mathrm{Sr}_{12} \mathrm{Al}_{14} \mathrm{O}_{33}$. The $\mathrm{BCC}$ phase, $\mathrm{Sr}_{12} \mathrm{Al}_{14} \mathrm{O}_{33}$, could be expressed as $\mathrm{Sr}_{1.714} \mathrm{Al}_{2} \mathrm{O}_{4.714}$ or $0.714 \mathrm{SrO} \bullet \mathrm{SrAl}_{2} \mathrm{O}_{4}$. Figure 4 shows the result of XRD analysis on the back side of the plasma-synthesized disc. There may be traces of $\mathrm{SrO}$ and $\mathrm{Al}_{2} \mathrm{O}_{3}$ remaining on this side of the disc. 

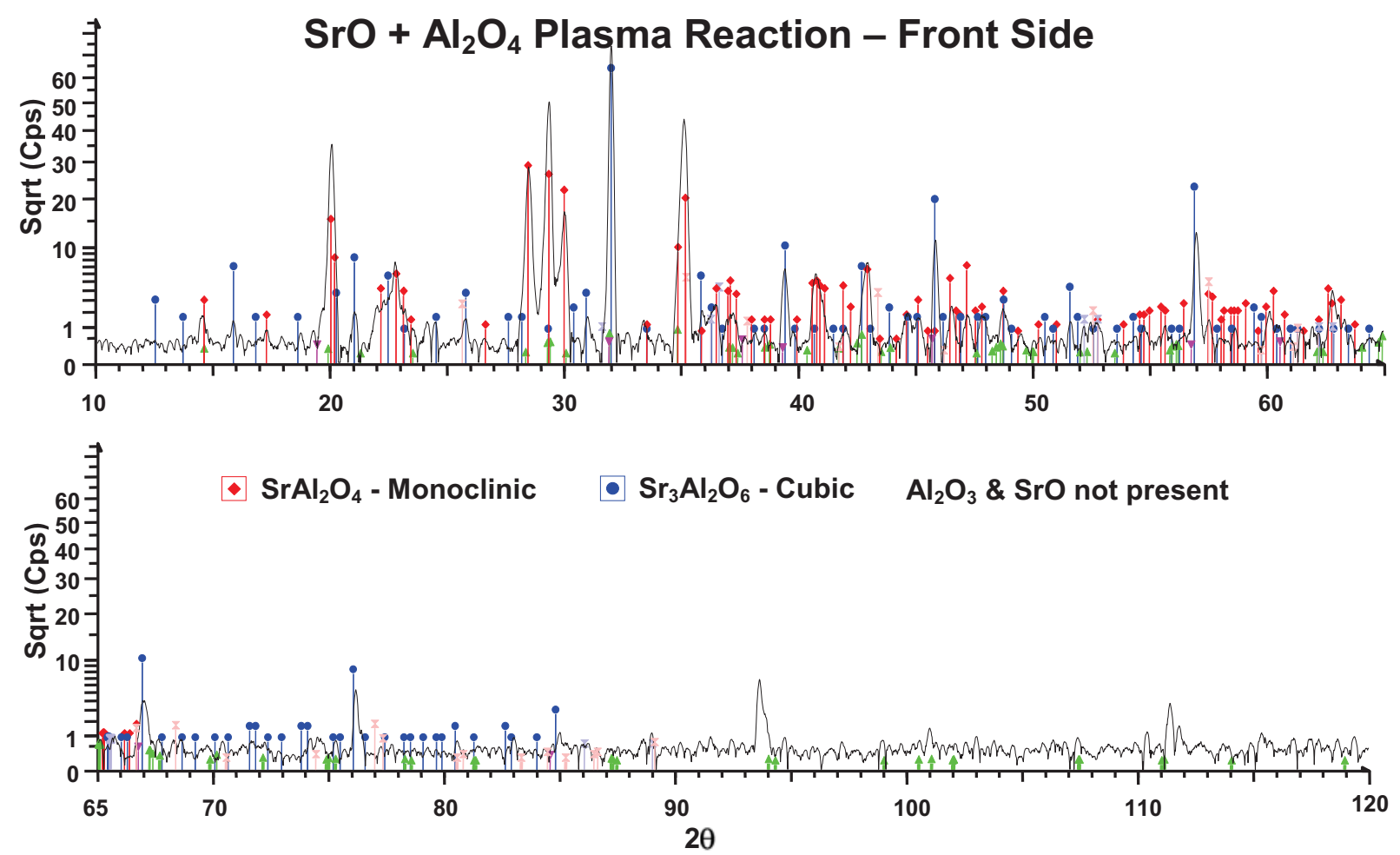

Figure 3. XRD analysis of the front side of the plasma-synthesized disc.
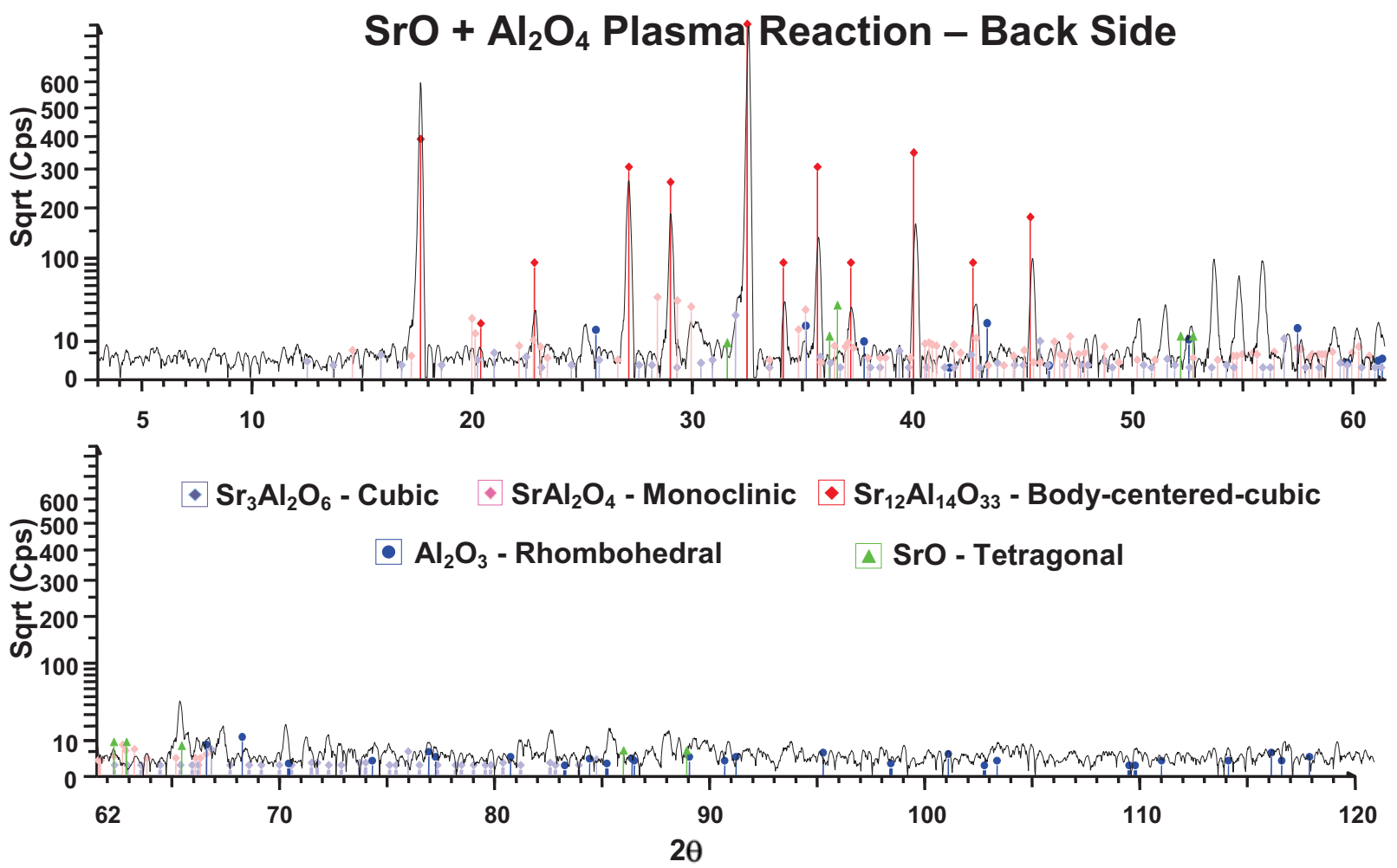

Figure 4. XRD analysis of the back side of the plasma-synthesized disc. 
The plasma-synthesized disc was further heat-treated in a furnace at $800^{\circ} \mathrm{C}$ for four hours to see if any composition changes would occur. After the furnace heat treatment, the plasma-heated side of the disc showed a significant phase precipitation. The XRD analysis for the plasma side of the disc after the $800^{\circ} \mathrm{C}$ heat treatment is shown in Figure 5. A BBC phase of $\mathrm{Sr}_{12} \mathrm{Al}_{14} \mathrm{O}_{33}\left(\mathrm{Sr}_{1.714} \mathrm{Al}_{2} \mathrm{O}_{4.714}\right.$ or $0.714 \mathrm{SrO} \bullet \mathrm{SrAl}_{2} \mathrm{O}_{4}$ ) became the dominant phase in the sample. The presence of a hexagonal phase $\mathrm{SrAl}_{2} \mathrm{O}_{4}$ appeared unlikely and the presence of a minor $\mathrm{FCC} \mathrm{Al}_{2} \mathrm{O}_{3}$ is possible. This side of the disc appeared light grey.

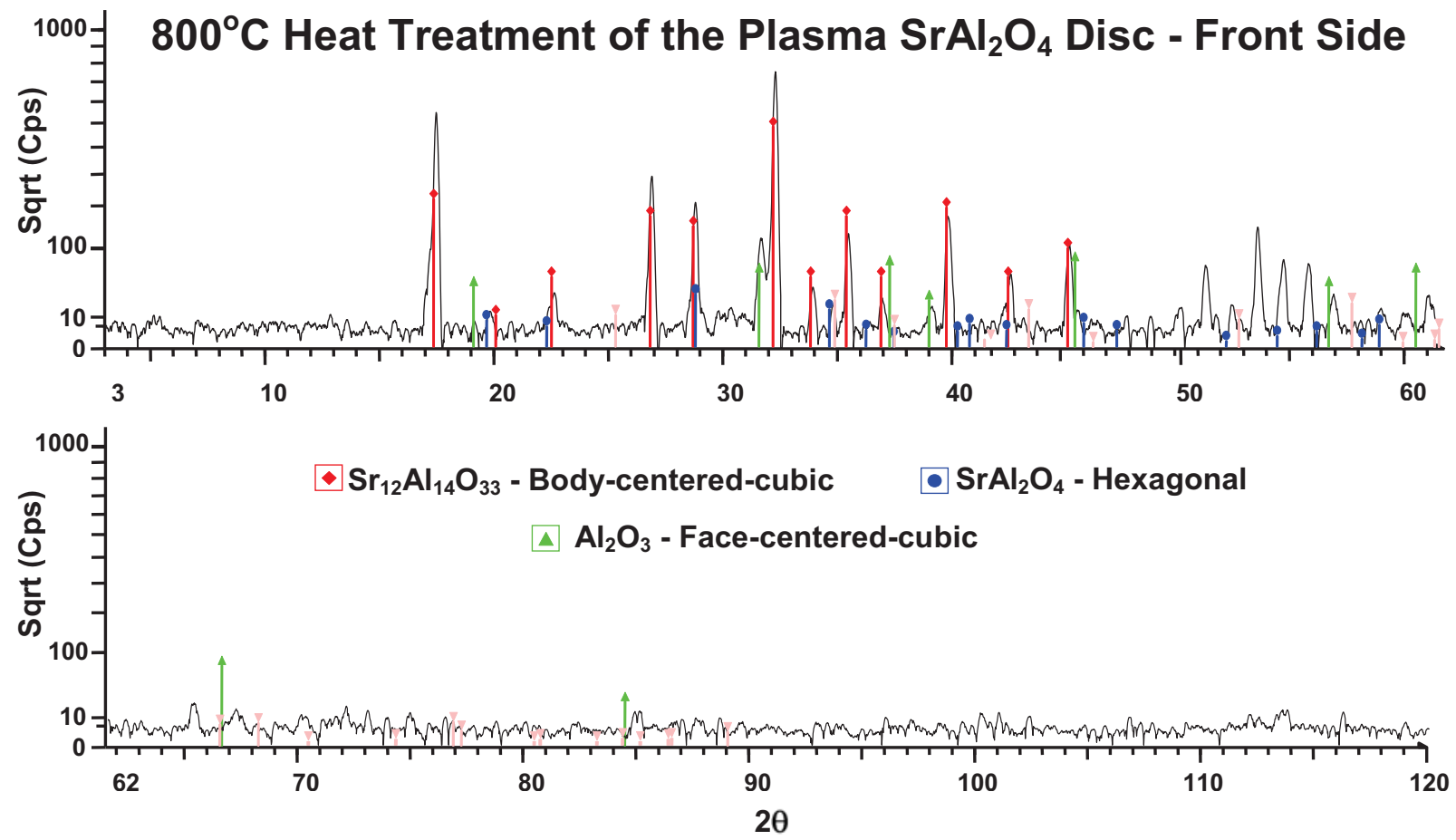

Figure 5. XRD analysis of the front side of the heat-treated plasma-synthesized disc.

However, the back side of the disc showed a completely different picture. Figure 6 shows the XRD analysis on the back side of the heat-treated plasma disc. The monoclinic $\mathrm{SrAl}_{2} \mathrm{O}_{4}$ phase and the simple cubic $\mathrm{Sr}_{3} \mathrm{Al}_{2} \mathrm{O}_{6}\left(2 \mathrm{SrO} \bullet \mathrm{SrAl}_{2} \mathrm{O}_{4}\right)$ phase were the only phases present. The difference in phase composition on both sides of the disc was very puzzling. By examining the XRD traces, the phase compositions of the front and back sides of the $800^{\circ} \mathrm{C}$ heat-treated sample are the exact opposite of the plasma-synthesized sample. Why this occurred is unknown. The temperature conditions for these phases to form are unknown. The color of the back side of the disc appeared dark grey.

The disc was further subjected to 12 hours of furnace heat treatment at $1350^{\circ} \mathrm{C}$. Only a single phase of $\mathrm{SrAl}_{2} \mathrm{O}_{4}$ and a residual amount of $\mathrm{Al}_{2} \mathrm{O}_{3}$ were detected throughout the disc after the heat treatment. Figure 7 shows the XRD analysis of the disc. The $\mathrm{SrAl}_{2} \mathrm{O}_{4}$ crystalline phase has $42.62 \%$ of Sr loading. The heat treatment indicated that the other strontium aluminates might be transitory phases at lower temperatures. 

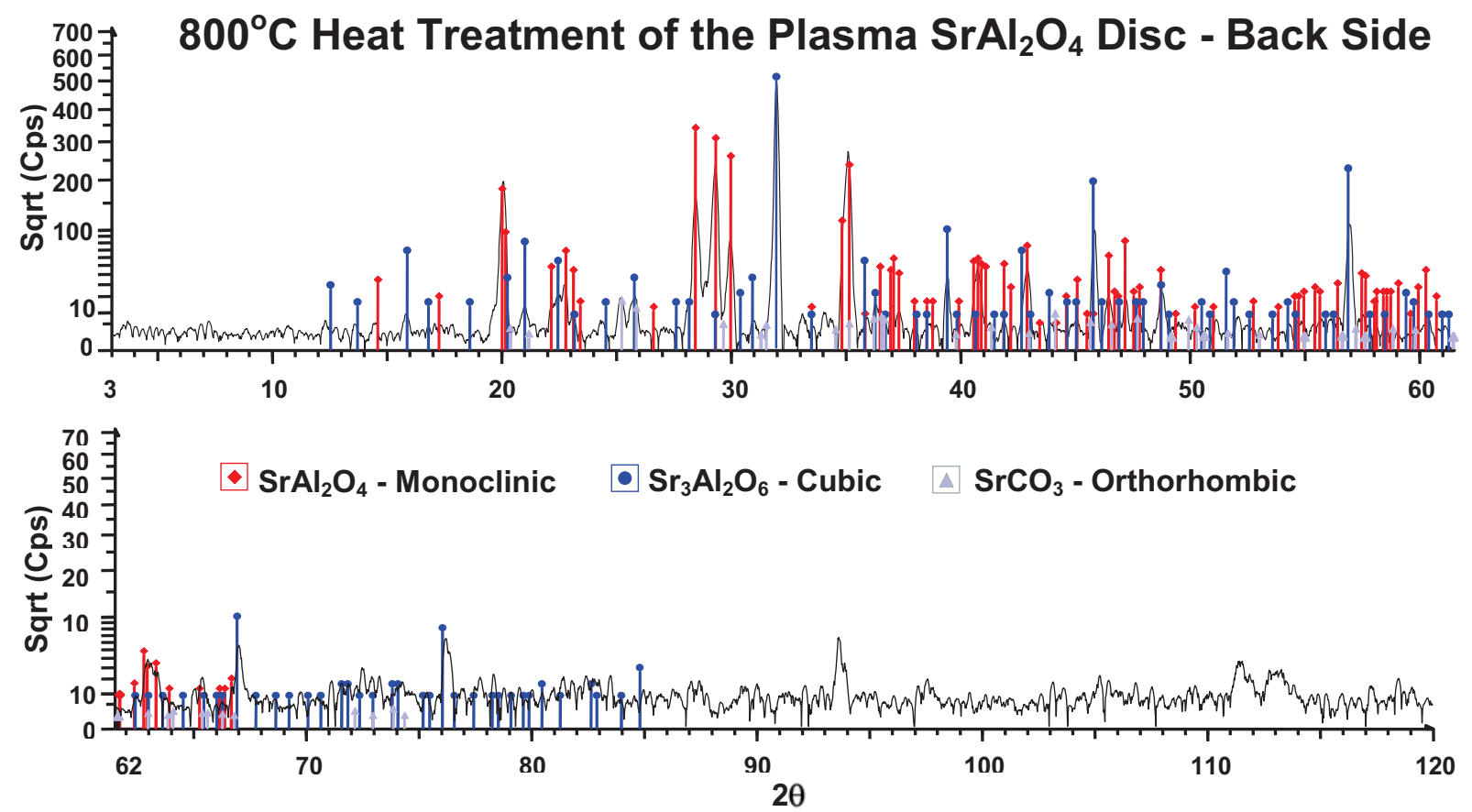

Figure 6. XRD analysis of the back side of the heat-treated plasma-synthesized disc.
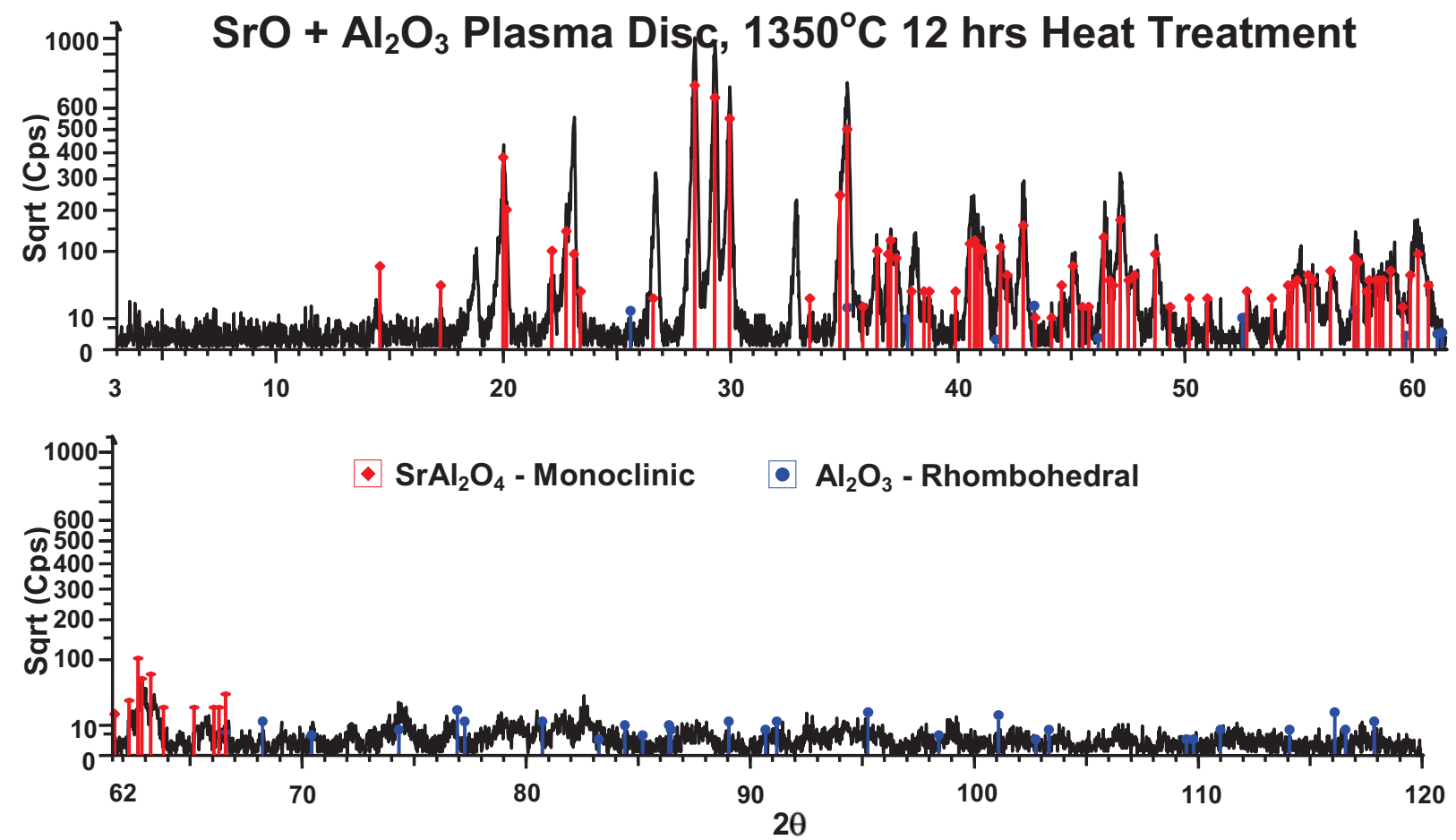

Figure 7. XRD analysis of the plasma disc after 12 hours of heat treatment at $1350^{\circ} \mathrm{C}$. 


\subsection{3 $\quad \mathrm{Mg}_{1-\mathrm{x}} \mathrm{Sr}_{\mathrm{x}} \mathrm{Al}_{2} \mathrm{O}_{4}$ Synthesis}

The synthesis of Sr-substituted MgA12O4 using mixed oxides followed the chemical equations below:

$0.75 \mathrm{MgO}+0.25 \mathrm{SrO}+\mathrm{Al}_{2} \mathrm{O}_{3} \rightarrow \mathrm{Mg}_{0.75} \mathrm{Sr}_{0.25} \mathrm{Al}_{2} \mathrm{O}_{4}$

$0.50 \mathrm{MgO}+0.50 \mathrm{SrO}+\mathrm{Al}_{2} \mathrm{O}_{3} \rightarrow \mathrm{Mg}_{0.50} \mathrm{Sr}_{0.50} \mathrm{Al}_{2} \mathrm{O}_{4}$

$0.25 \mathrm{MgO}+0.75 \mathrm{SrO}+\mathrm{Al}_{2} \mathrm{O}_{3} \rightarrow \mathrm{Mg}_{0.25} \mathrm{Sr}_{0.75} \mathrm{Al}_{2} \mathrm{O}_{4}$

$\mathrm{MgO}, \mathrm{SrO}$, and $\mathrm{Al}_{2} \mathrm{O}_{3}$ powders for the above reactions were well mixed and then heated in a furnace at $1350^{\circ} \mathrm{C}$ for 12 hours. The reaction was not complete at $1350^{\circ} \mathrm{C}$ and significant amount of $\mathrm{MgO}$ remained. At a high $\mathrm{SrO}$ concentration $(0.75$ mole $)$, the formation of $\mathrm{SrAl}_{2} \mathrm{O}_{4}$ is favored. XRD analyses of the reactions are shown in Figure 8 for reaction A, Figure 9 for reaction $\mathrm{B}$, and Figure 10 for reaction $\mathrm{C}$. The substitution of $\mathrm{Sr}$ into $\mathrm{MgAl}_{2} \mathrm{O}_{4}$ to form a FCC $\mathrm{Sr}_{\mathrm{x}} \mathrm{Mg}_{1-\mathrm{x}} \mathrm{Al}_{2} \mathrm{O}_{4}$ spinel solid solution with $\mathrm{x}$ ranged between 0.25 and 0.75 was not observed. The proposed compositions may not exist at all. In the $\mathrm{MgO}, \mathrm{SrO}$, and $\mathrm{Al}_{2} \mathrm{O}_{3}$ systems, only one ternary complex oxide was observed and not a spinel. The complex ternary oxide, $\mathrm{MgSrAl}_{10} \mathrm{O}_{17}$, has $13.40 \%$ of $\mathrm{Sr}$ in its structure. Other strontium aluminate phases identified included $\mathrm{SrAl}_{12} \mathrm{O}_{19}(\mathrm{Sr} 12.25 \%), \mathrm{Sr}_{3} \mathrm{Al}_{32} \mathrm{O}_{51}(\mathrm{Sr} 13.53 \%), \mathrm{SrAl}_{2} \mathrm{O}_{4}(\mathrm{Sr} 42.62 \%), \mathrm{Sr}_{12} \mathrm{Al}_{14} \mathrm{O}_{33}(\mathrm{Sr} 53.72 \%)$, and $\mathrm{Sr}_{3} \mathrm{Al}_{2} \mathrm{O}_{6}(\mathrm{Sr} 63.67 \%)$. From a cation size stand point, $\mathrm{Mg}^{2+}$ is $0.65 \AA, \mathrm{Sr}^{2+}$ is $1.13 \AA$, and the cation ratio of $\mathrm{Mg}^{2+} / \mathrm{Sr}^{2+}$ is 0.5752 . $\mathrm{Sr}^{2+}$ is too large to fit into the $\mathrm{MgAl}_{2} \mathrm{O}_{4}$ crystal structure. This may be the reason that $\mathrm{Sr}_{\mathrm{x}} \mathrm{Mg}_{1-\mathrm{x}} \mathrm{Al}_{2} \mathrm{O}_{4} \mathrm{FCC}$ spinel solid solutions may not exist.
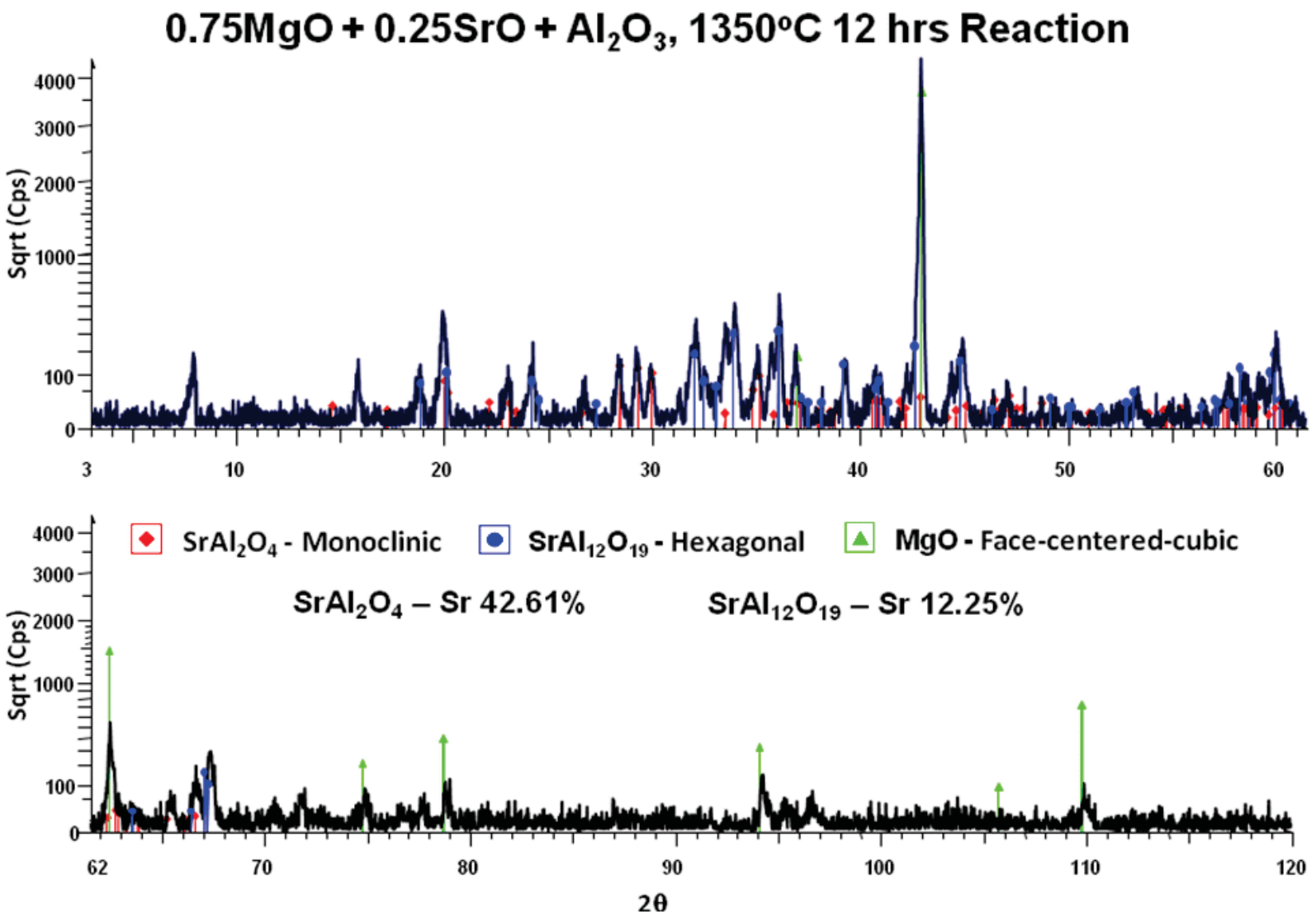

Figure 8. XRD analysis of $0.75 \mathrm{MgO}+0.25 \mathrm{SrO}+\mathrm{Al}_{2} \mathrm{O}_{3} \rightarrow \mathrm{Mg}_{0.75} \mathrm{Sr}_{0.25} \mathrm{Al}_{2} \mathrm{O}_{4}$ reaction. 

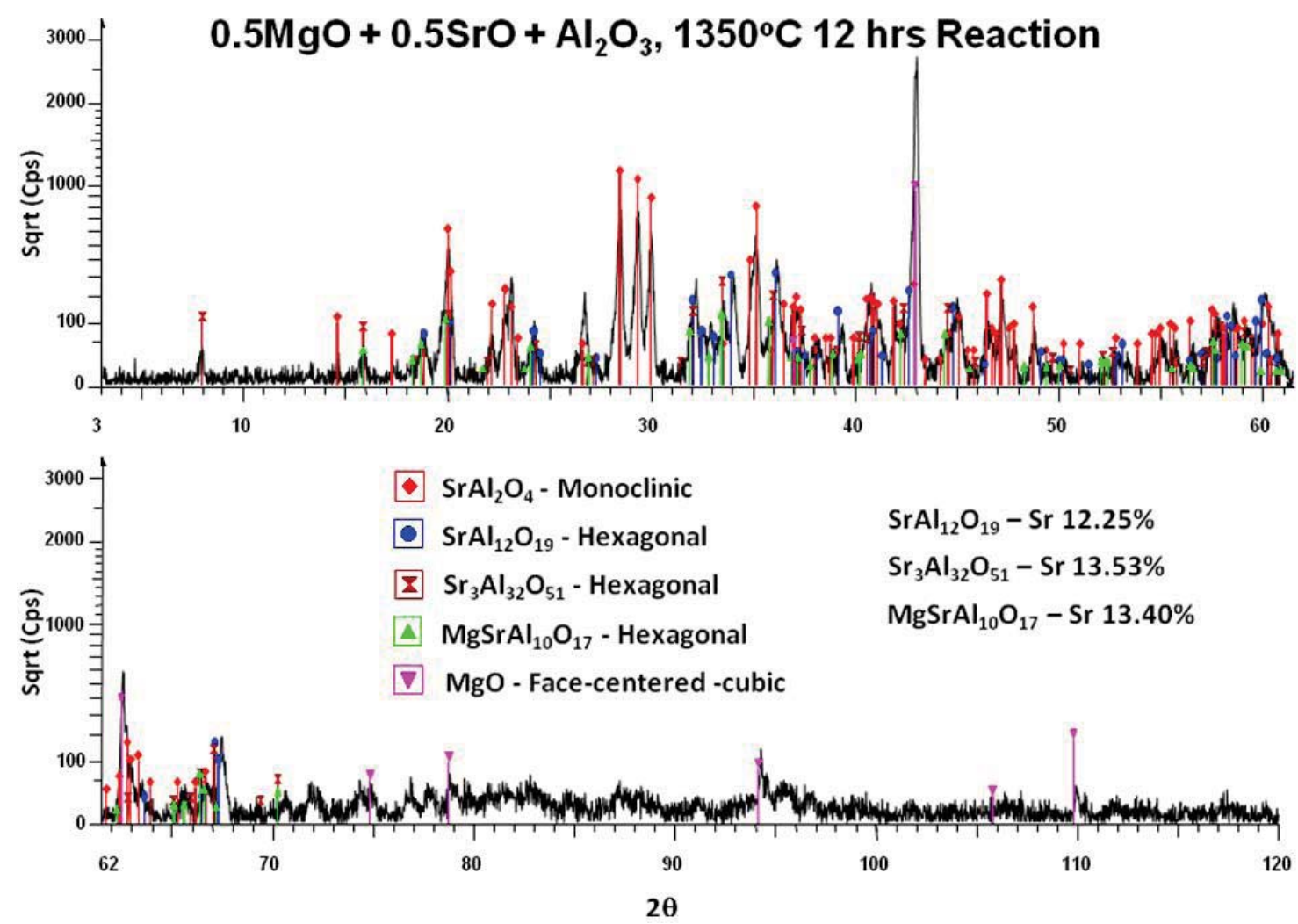

Figure 9. XRD analysis of $0.5 \mathrm{MgO}+0.5 \mathrm{SrO}+\mathrm{Al}_{2} \mathrm{O}_{3} \rightarrow \mathrm{Mg}_{0.5} \mathrm{Sr}_{0.5} \mathrm{Al}_{2} \mathrm{O}_{4}$ reaction.
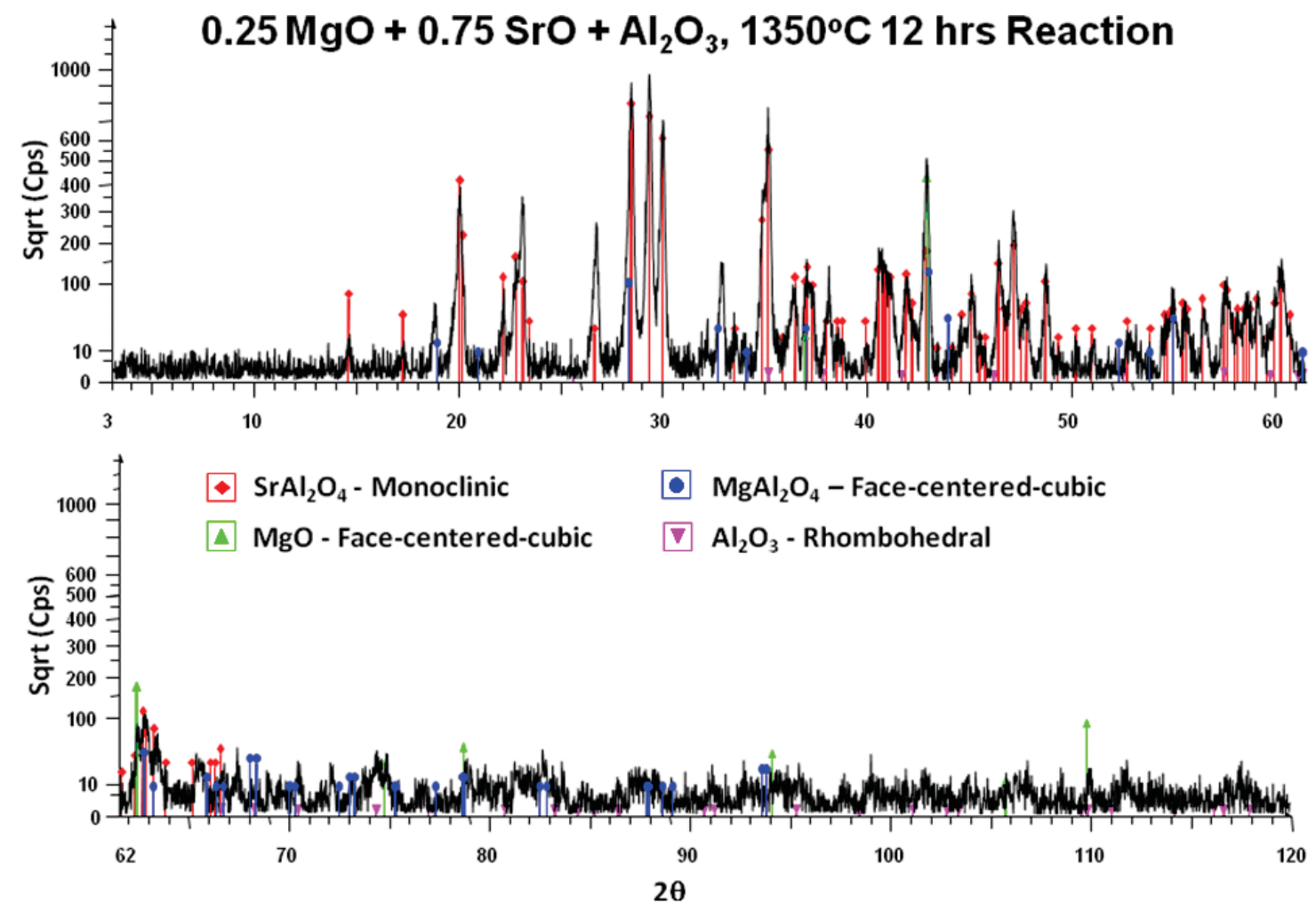

Figure 10. XRD analysis of $0.25 \mathrm{MgO}+0.75 \mathrm{SrO}+\mathrm{Al}_{2} \mathrm{O}_{3} \rightarrow \mathrm{Mg}_{0.25} \mathrm{Sr}_{0.75} \mathrm{Al}_{2} \mathrm{O}_{4}$ reaction. 
Since $\mathrm{Sr}^{2+}$ is too large to fit into the $\mathrm{MgAl}_{2} \mathrm{O}_{4}$ crystal structure and form a spinel structure, a different ceramic host must be identified to immobilize $\mathrm{Sr}$. The size of $\mathrm{Ca}^{2+}$ is much closer to $\mathrm{Sr}^{2+}$ and $\mathrm{Sr}$ would have a better chance to substitute into the $\mathrm{CaAl}_{2} \mathrm{O}_{4}$ lattice.

\subsubsection{Synthesis of $\mathrm{CaAl}_{2} \mathrm{O}_{4}$}

The $\mathrm{CaAl}_{2} \mathrm{O}_{4}$ synthesis was carried out in a plasma reaction using mixed nitrate solutions. The plasma reaction to produce the powder was extremely fast. However, powder collection and recovery was very poor because of the nanoparticle size produced for the product. The analysis of plasma-synthesized $\mathrm{CaAl}_{2} \mathrm{O}_{4}$ powder is shown in Figure 11 and XRD analysis revealed that the crystalline structure of calcium aluminate is monoclinic.

The plasma-produced $\mathrm{CaAl}_{2} \mathrm{O}_{4}$ powder was heat-treated at $650^{\circ} \mathrm{C}, 1150^{\circ} \mathrm{C}$, and $1300^{\circ} \mathrm{C}$ for two hours each to grow the particle size. XRD analysis (see Figure 12) on the $1150^{\circ} \mathrm{C}$ heat-treated powder showed a single phase monoclinic crystalline structure and the composition was matched to $\mathrm{CaAl}_{2} \mathrm{O}_{4}$. When compared to $\mathrm{SrAl}_{2} \mathrm{O}_{4}$, which is also monoclinic, the crystallographic unit cell of $\mathrm{CaAl}_{2} \mathrm{O}_{4}$ is smaller than $\mathrm{SrAl}_{2} \mathrm{O}_{4}$ because the $\mathrm{Ca}^{2+}$ ion size is smaller than the $\mathrm{Sr}^{2+}$ ion. The main feature of $\mathrm{SrAl}_{2} \mathrm{O}_{4}$ is a triplet located between $28.46^{\circ}$ and $30.00^{\circ} 2 \theta$, while the main feature for $\mathrm{CaAl}_{2} \mathrm{O}_{4}$ is a quadruplet located between $30.00^{\circ}$ and $31.40^{\circ} 2 \theta$. Both $\mathrm{Ca}_{3} \mathrm{Al}_{2} \mathrm{O}_{6}$ and $\mathrm{Ca}_{12} \mathrm{Al}_{14} \mathrm{O}_{33}$ were also matched by XRD. However, their presence was not evident in the product. In the $\mathrm{SrAl}_{2} \mathrm{O}_{4}$ work, $\mathrm{Sr}_{3} \mathrm{Al}_{2} \mathrm{O}_{6}$ and $\mathrm{Sr}_{12} \mathrm{Al}_{14} \mathrm{O}_{33}$ were identified and their crystalline structures were also identical to that of the calcium aluminates. Strontium should be able to substitute for $\mathrm{Ca}$ ions in the crystal structure. The next step is to synthesize the Sr-substituted $\mathrm{CaAl}_{2} \mathrm{O}_{4}$.

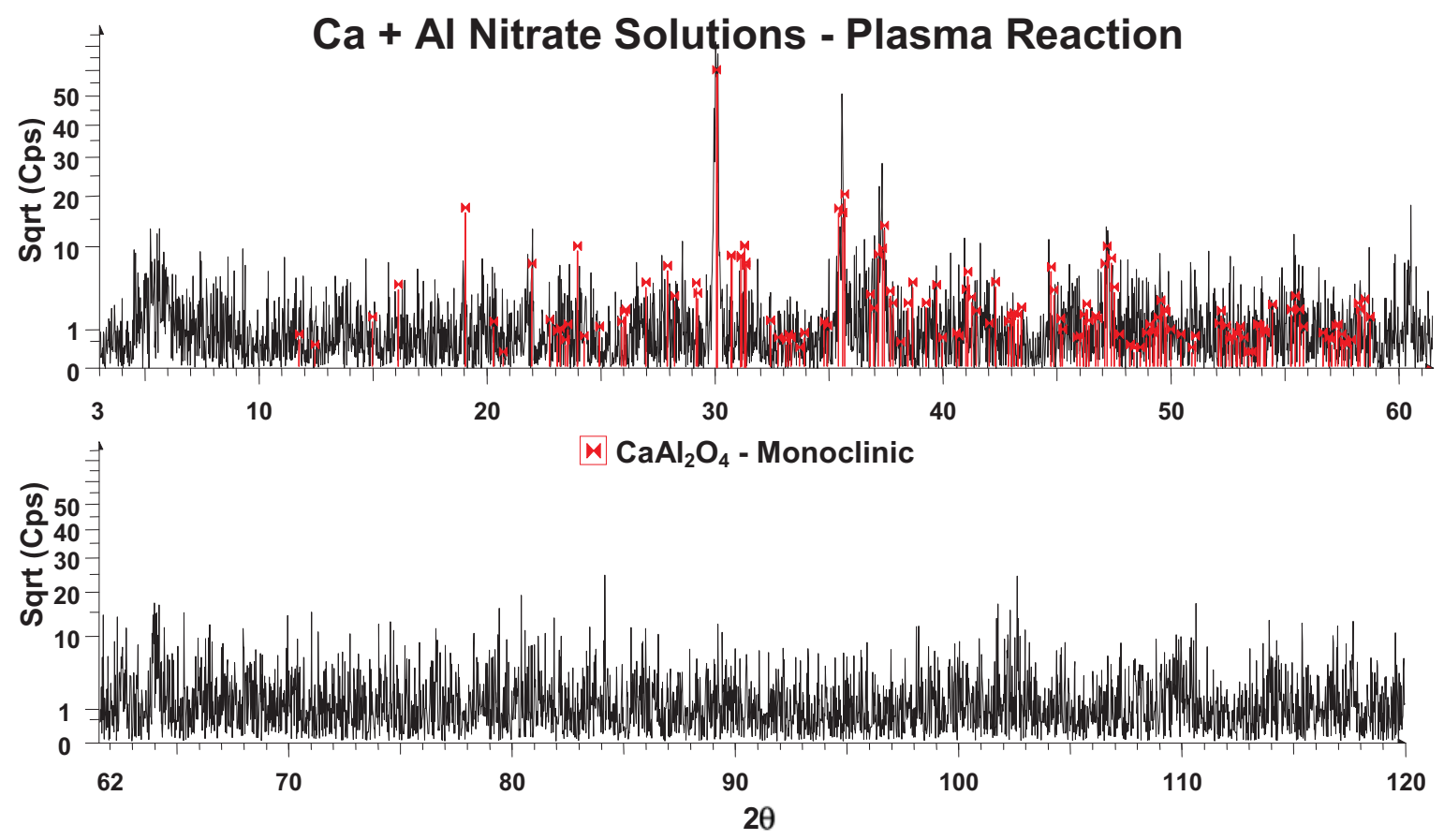

Figure 11. XRD analysis of plasma-synthesized $\mathrm{CaAl}_{2} \mathrm{O}_{4}$ from mixed nitrate solutions. 


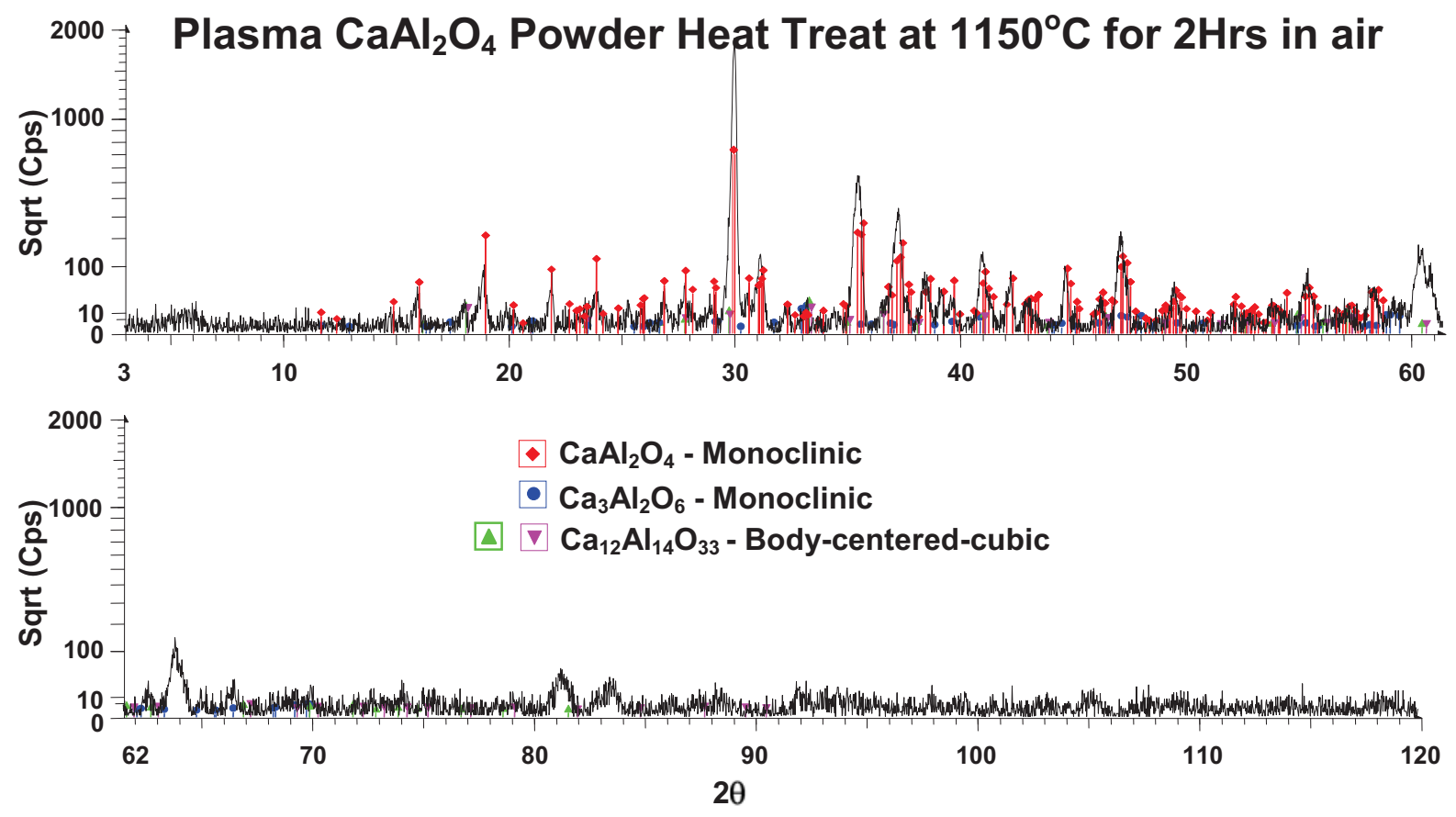

Figure 12. XRD analysis of heat-treated plasma-synthesized $\mathrm{CaAl}_{2} \mathrm{O}_{4}$ powder.

\subsubsection{Synthesis of $\mathrm{Ca}_{0.5} \mathrm{Sr}_{0.5} \mathrm{Al}_{2} \mathrm{O}_{4}$}

Strontium-substituted $\mathrm{Ca}_{0.5} \mathrm{Sr}_{0.5} \mathrm{Al}_{2} \mathrm{O}_{4}$ was prepared using mixed powders and reacted in a hightemperature furnace using a platinum crucible. After 89 hours of heating at $1350^{\circ} \mathrm{C}$, the product was examined by XRD analysis. Multiple phases were formed in the product. The product partially resembled both $\mathrm{CaAl}_{2} \mathrm{O}_{4}$ and $\mathrm{SrAl}_{2} \mathrm{O}_{4}$. A second heating on the product was performed at $1650^{\circ} \mathrm{C}$ for another three hours. XRD analysis showed significant crystallization from the initial $1350^{\circ} \mathrm{C}$ product and the number of diffraction peaks decreased. The product did not match any know phase. A third heating was performed on the product at $1650^{\circ} \mathrm{C}$ for 66 additional hours to further the reaction. In Figure 13, the XRD pattern of the third heating product showed further sharpening up of the diffraction lines and also showed a little more crystallization of the product. However, the diffraction pattern remained constant when compared to the initial three hour heating treatment at $1650^{\circ} \mathrm{C}$, indicating that the reaction might have been completed. The final product did not match any know phase. However, the most intense diffraction lines of the final product lied between the quadruplets of $\mathrm{CaAl}_{2} \mathrm{O}_{4}$ (green) and the triplets of $\mathrm{SrAl}_{2} \mathrm{O}_{4}$ (red). $\mathrm{The} \mathrm{CaAl}_{2} \mathrm{O}_{4}$ has a quadruplet between $29.59^{\circ}$ and $31.08^{\circ} 2 \theta$ and $\mathrm{SrAl}_{2} \mathrm{O}_{4}$ has a triplet between $28.46^{\circ}$ and $29.96^{\circ} 2 \theta$. However, the final product has only two lines at $29.75^{\circ}$ and $31.00^{\circ} 2 \theta$. The crystalline structure of this strontium substation phase should be monoclinic. Based on the crystal plane d-spacing, the lattice dimensions should be slightly larger than $\mathrm{CaAl}_{2} \mathrm{O}_{4}$, but smaller than $\mathrm{SrAl}_{2} \mathrm{O}_{4}$. 


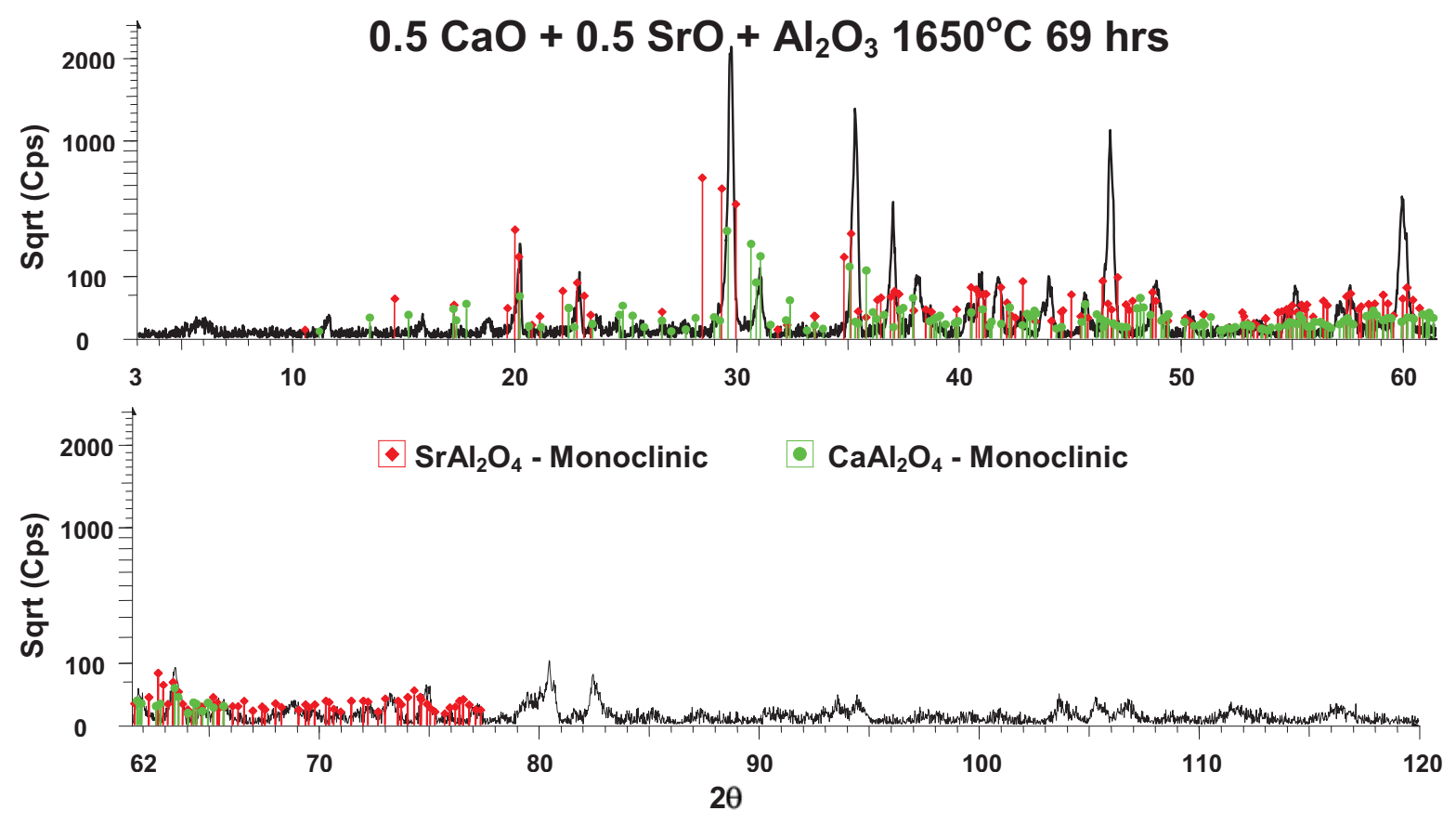

Figure 13. XRD analysis shows the $0.5 \mathrm{CaO}+0.5 \mathrm{SrO}+\mathrm{Al}_{2} \mathrm{O}_{3}$ reaction product.

SEM-EDX analysis was performed on the initial $1350^{\circ} \mathrm{C}$ reaction product to assess the $\mathrm{Ca}$ and $\mathrm{Sr}$ distributions in the particles. SEM morphology of the sintered particles for the 86 hours $1350^{\circ} \mathrm{C}$ reaction product is shown in Figures 14a and 14b. At this reaction temperature, the particles showed significant surface melting as seen in Figure 14b micrographs B through E. The majority of the reacted product, more than $95 \%$, showed the morphology in pictures B and C. Occasionally, some particles showed partial melting and sintering morphologies as shown in micrographs D and E. These particles might be underreacted when compared to the rest of the material.

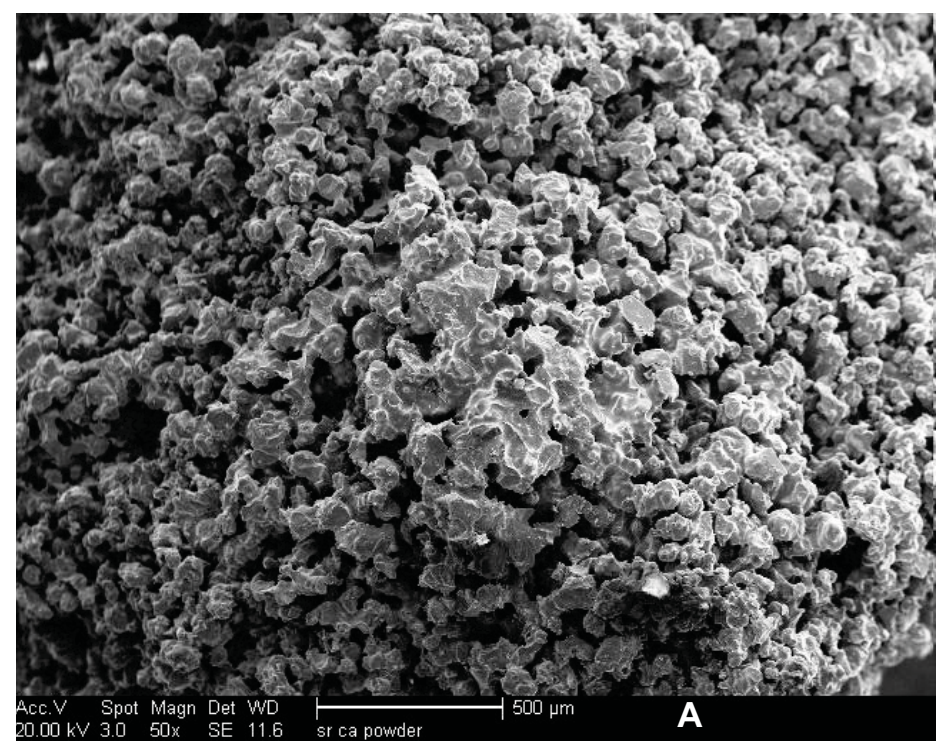

Figure 14a. SEM micrograph shows the morphology of the sintered particles for the 86 hours $1350^{\circ} \mathrm{C}$ reaction product. 

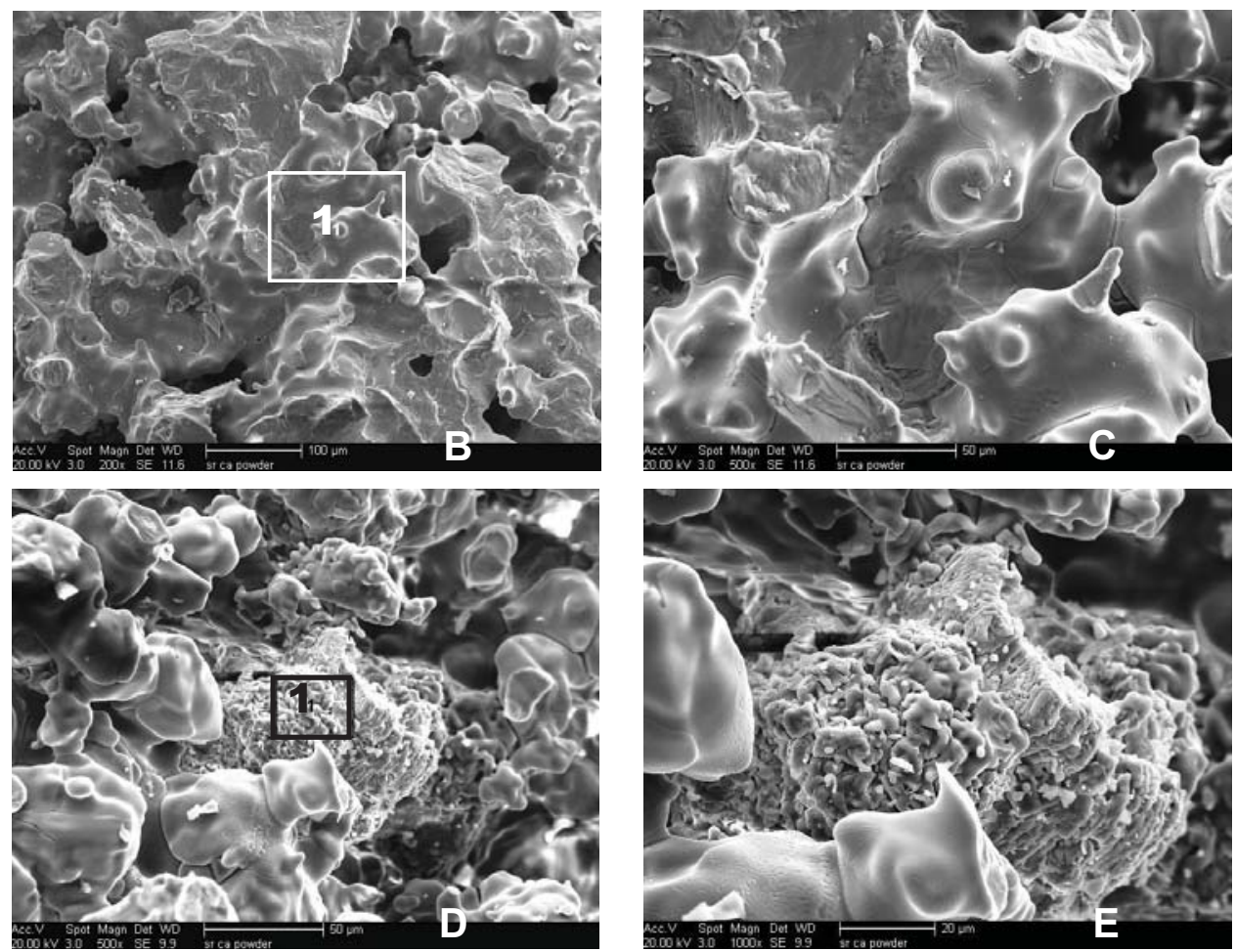

Figure 14b. SEM analysis of $\mathrm{Ca}_{0.5} \mathrm{Sr}_{0.5} \mathrm{Al}_{2} \mathrm{O}_{4}$ product synthesized at $1350^{\circ} \mathrm{C}$ for 86 hours.

EDX analyses were performed on these two types of particle morphologies to investigate the chemical compositions. The EDX analysis of elemental compositions on white spot 1 (molten) is shown in Figure 15a. The normalized mole \% for this particle is shown in the table insert. The empirical formula from this composition can be expressed as $\mathrm{Ca}_{0.35} \mathrm{Sr}_{0.65} \mathrm{Al}_{2} \mathrm{O}_{3.65}$ and is approaching the targeted composition of $\mathrm{Ca}_{0.5} \mathrm{Sr}_{0.5} \mathrm{Al}_{2} \mathrm{O}_{4}$.

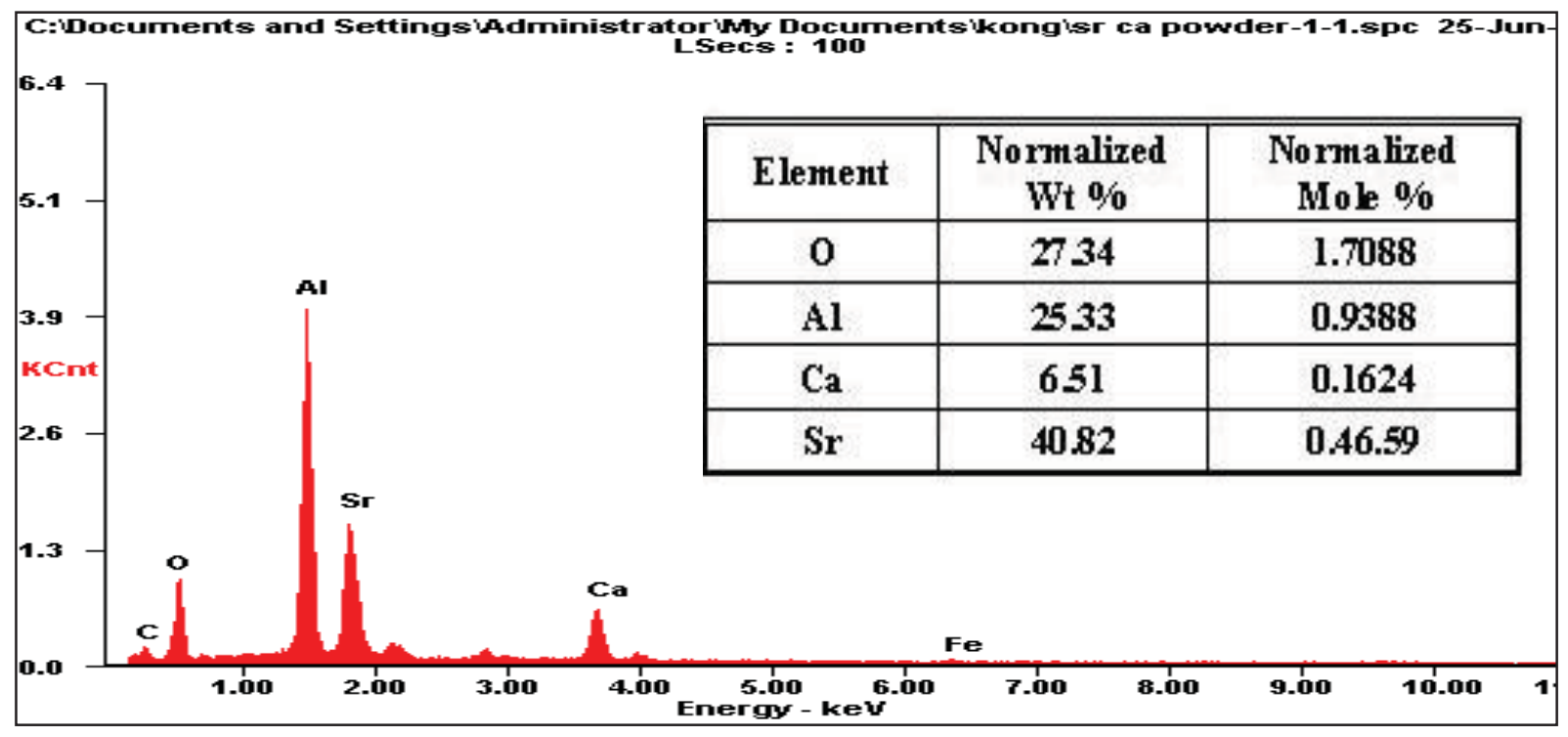

Figure 15a. EDX analysis on white spot 1 in Figure 14b.

The EDX analysis of elemental compositions on the black spot 1 (partially molten and sintered) is shown in Figure 15b. The normalized mole \% for this particle is shown in the table insert. This lump of particles 
has significantly lower strontium concentration. The empirical formula from this composition can be expressed as $\mathrm{Ca}_{0.24} \mathrm{Sr}_{0.13} \mathrm{Al}_{2} \mathrm{O}_{3.25}$ and is not that close to the composition of $\mathrm{Ca}_{0.5} \mathrm{Sr}_{0.5} \mathrm{Al}_{2} \mathrm{O}_{4}$. Further reaction is needed with surrounding product to move the composition to the target. The EDX analysis on the $1350^{\circ} \mathrm{C}$ intermediate reaction product is preliminary and EDX analysis will need to be performed on the $1650^{\circ} \mathrm{C}$ final reaction product.

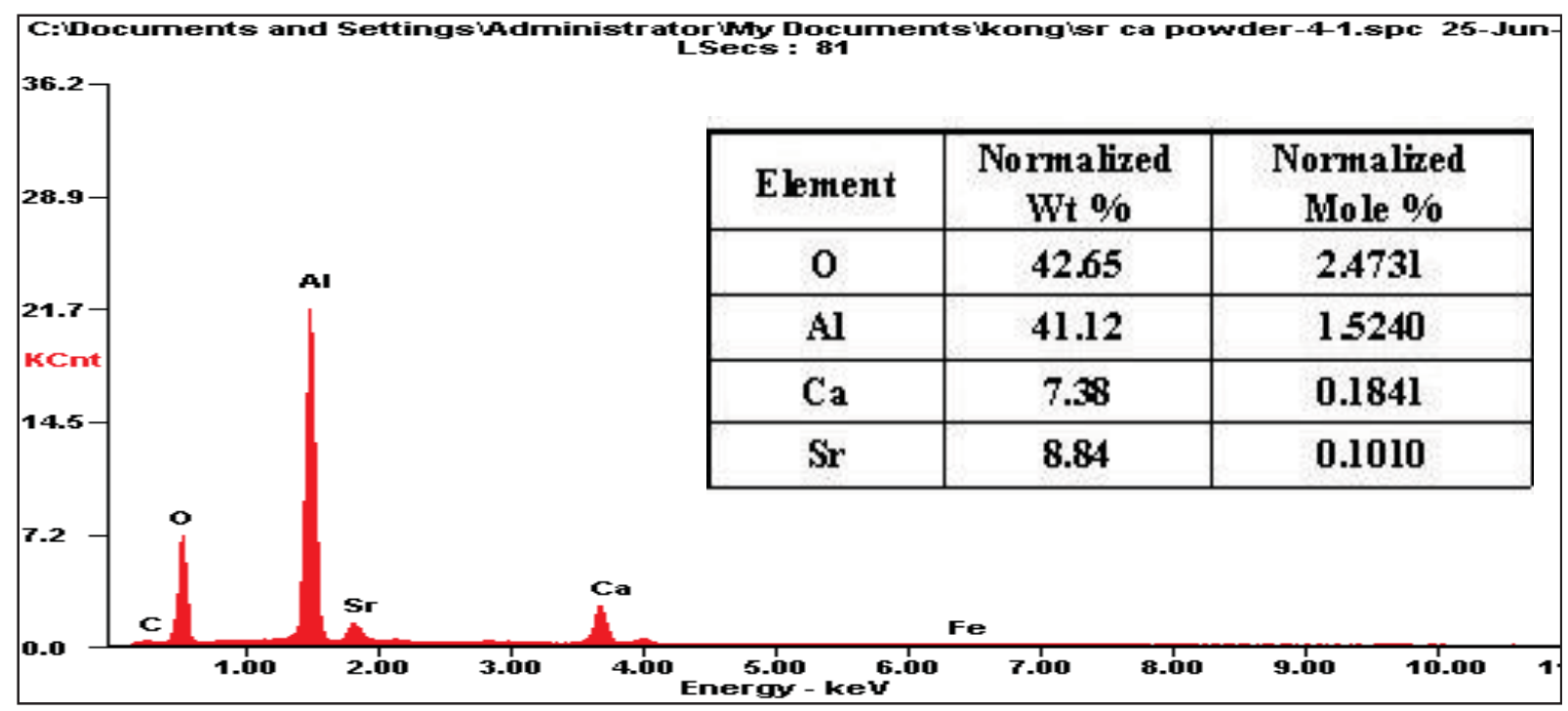

Figure 15b. EDX analysis on black spot 1 in Figure 14b.

\subsubsection{Synthesis of $\mathrm{CaTiO}_{3}, \mathrm{SrTiO}_{3}$ and $\mathrm{Ca}_{1-\mathrm{x}} \mathrm{Sr}_{\mathrm{x}} \mathrm{TiO}_{3}$}

The synthesis of $\mathrm{CaTiO}_{3}, \mathrm{SrTiO}_{3}$, and $\mathrm{Ca}_{1-\mathrm{x}} \mathrm{Sr}_{\mathrm{x}} \mathrm{TiO}_{3}$ using mixed oxides followed the chemical equations below:

$\mathrm{CaO}+\mathrm{TiO}_{2} \rightarrow \mathrm{CaTiO}_{3}$

$0.75 \mathrm{CaO}+0.25 \mathrm{SrO}+\mathrm{TiO}_{2} \rightarrow \mathrm{Ca}_{0.75} \mathrm{Sr}_{0.25} \mathrm{TiO}_{3}$

$0.50 \mathrm{CaO}+0.50 \mathrm{SrO}+\mathrm{TiO}_{2} \rightarrow \mathrm{Ca}_{0.50} \mathrm{Sr}_{0.50} \mathrm{TiO}_{3}$

$0.25 \mathrm{CaO}+0.75 \mathrm{SrO}+\mathrm{TiO}_{2} \rightarrow \mathrm{Ca}_{0.25} \mathrm{Sr}_{0.75} \mathrm{TiO}_{3}$

$\mathrm{SrO}+\mathrm{TiO}_{2} \rightarrow \mathrm{SrTiO}_{3}$.

\subsection{7 $\quad \mathrm{CaTiO}_{3}$ Synthesis}

In the reaction to form $\mathrm{CaTiO}_{3}$, the $\mathrm{CaO}$ and $\mathrm{TiO}_{2}$ were heated at $1350^{\circ} \mathrm{C}$ for 16 hours. Figure 16 a shows the XRD analysis results. $\mathrm{CaTiO}_{3}$ forms the major product; a small amount of the starting oxides did not react. 

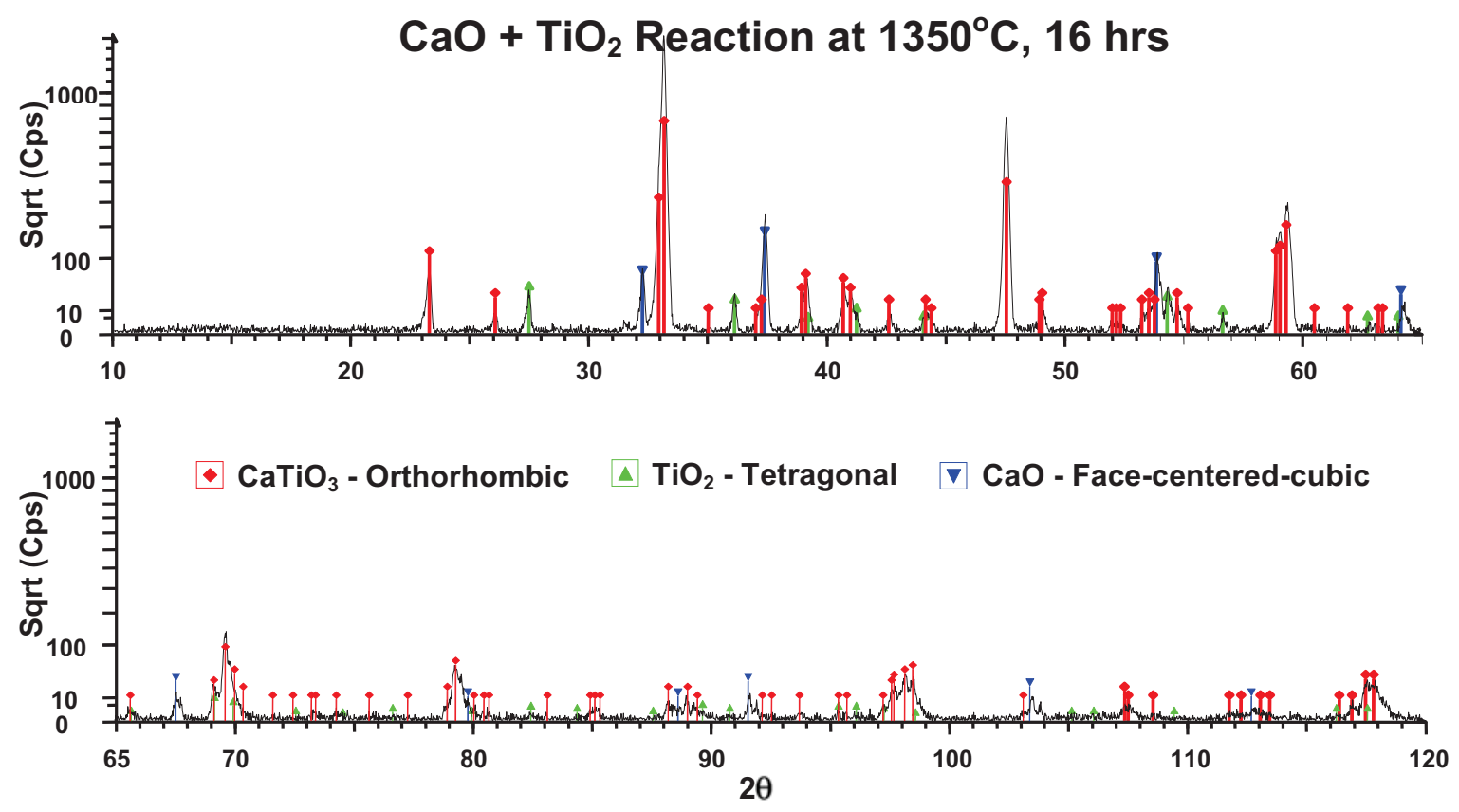

Figure 16a. XRD analysis of $\mathrm{CaO}+\mathrm{TiO}_{2}$ reaction product produced at $1350^{\circ} \mathrm{C}$.

The $\mathrm{CaO}$ and $\mathrm{TiO}_{2}$ were further heated at $1650^{\circ} \mathrm{C}$ for another 16 hours. The product reacted with the bottom of the alumina crucible and formed a solid melt. The solid melt was cut from the crucible and an XRD analysis was performed. In the analysis, $\mathrm{CaTiO}_{3}$ was the major product. Minor impurity phases of $\mathrm{CaAl}_{12} \mathrm{O}_{19}$ and $\mathrm{Ca}_{3} \mathrm{Ti}_{8} \mathrm{Al}_{12} \mathrm{O}_{37}$ were also matched. The impurity phases may have resulted from reactions of $\mathrm{CaO}$ and $\mathrm{TiO}_{2}$ with the alumina crucible. Figure $16 \mathrm{~b}$ shows the XRD analysis results; the evidence of $\mathrm{Ca}_{3} \mathrm{Ti}_{8} \mathrm{Al}_{12} \mathrm{O}_{37}$ in the product is not strong.
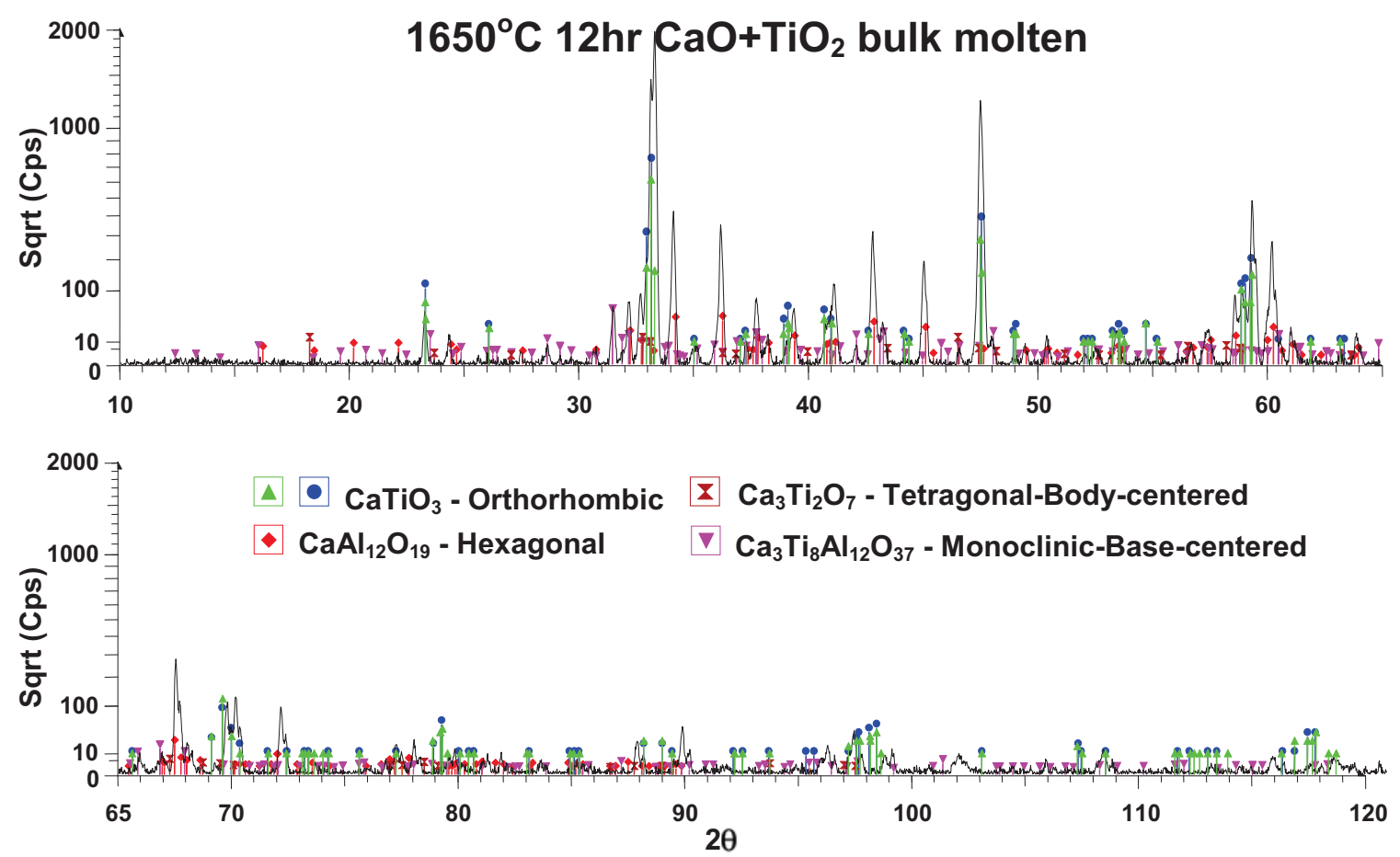

Figure $16 \mathrm{~b}$. XRD analysis of $\mathrm{CaO}+\mathrm{TiO} 2$ reaction product reacted at $1650^{\circ} \mathrm{C}$. 


\subsubsection{SrTiO3 Synthesis}

In the reaction to form $\mathrm{SrTiO}_{3}$, the $\mathrm{SrO}$ and $\mathrm{TiO}_{2}$ were heated at $1350^{\circ} \mathrm{C}$ for 16 hours. Most of the starting oxides reacted to form two strontium titanates, $\mathrm{Sr}_{2} \mathrm{TiO}_{4}$ and $\mathrm{SrTiO}_{3}$. Figure 17a shows the XRD results for the $1350^{\circ} \mathrm{C}$ run. $\mathrm{SrTiO}_{3}$ formed the major product. A minor $\mathrm{Sr}_{2} \mathrm{TiO}_{4}$ phase was also present. Only a small amount of the starting titanium oxide remained unreacted. The product was further heat-treated at $1650^{\circ} \mathrm{C}$ for 16 hours. XRD of the final product, as shown in Figure 17b, showed pretty much a single phase of $\mathrm{SrTiO}_{3}$ formed from the heat treatment. This shows $\mathrm{Sr}_{2} \mathrm{TiO}_{4}$ is unstable at temperatures between $1350^{\circ} \mathrm{C}$ and $1650^{\circ} \mathrm{C}$. Nevertheless, $\mathrm{Sr}_{2} \mathrm{TiO}_{4}$ is still a very high-temperature material and is good for radioactive $\mathrm{Sr}$ immobilization. There might have been a questionable trace amount of $\mathrm{TiO}_{2}$ remaining in the product.

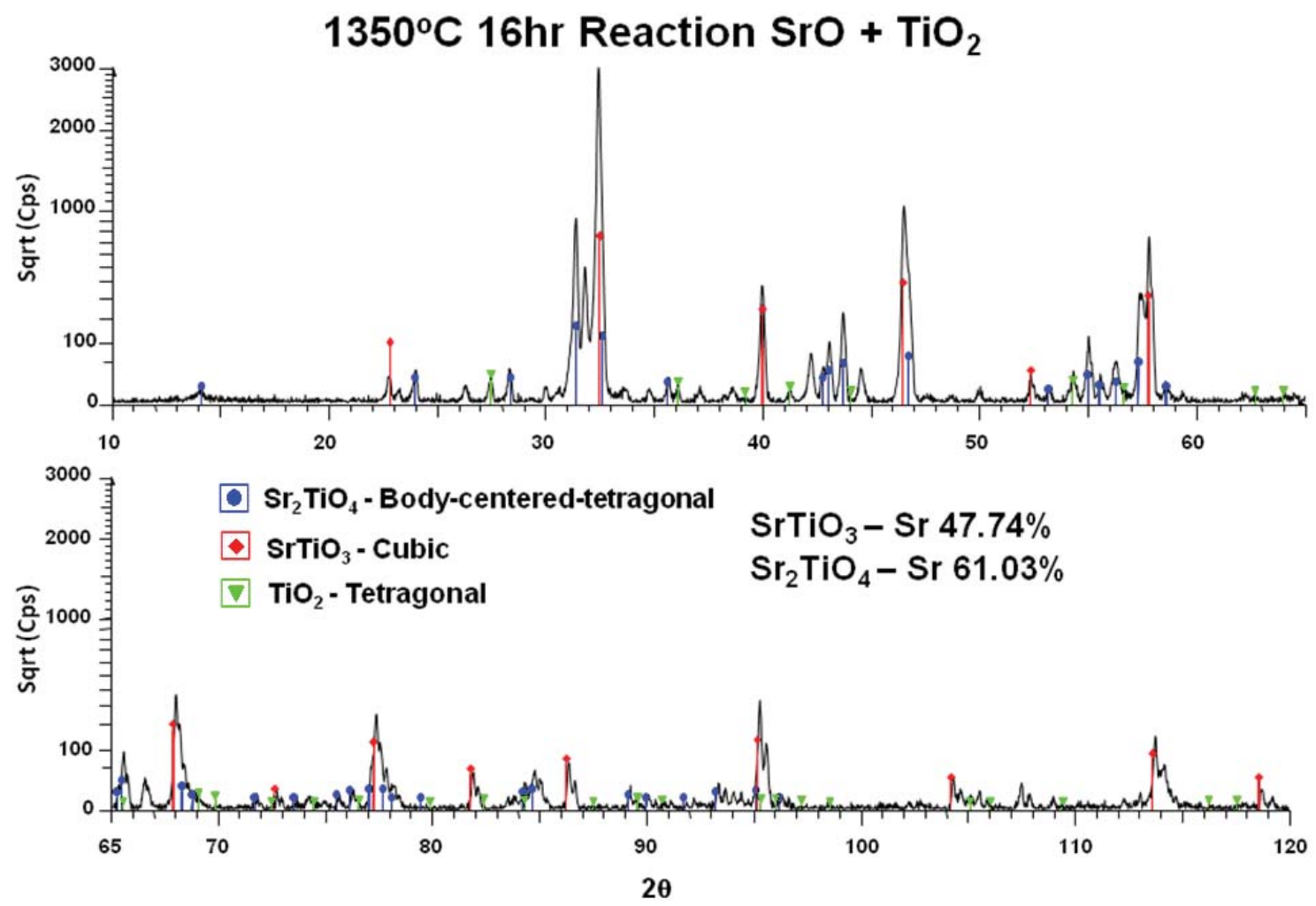

Figure 17a. XRD analysis of $\mathrm{SrO}+\mathrm{TiO}_{2}$ reaction at $1350^{\circ} \mathrm{C}$. 

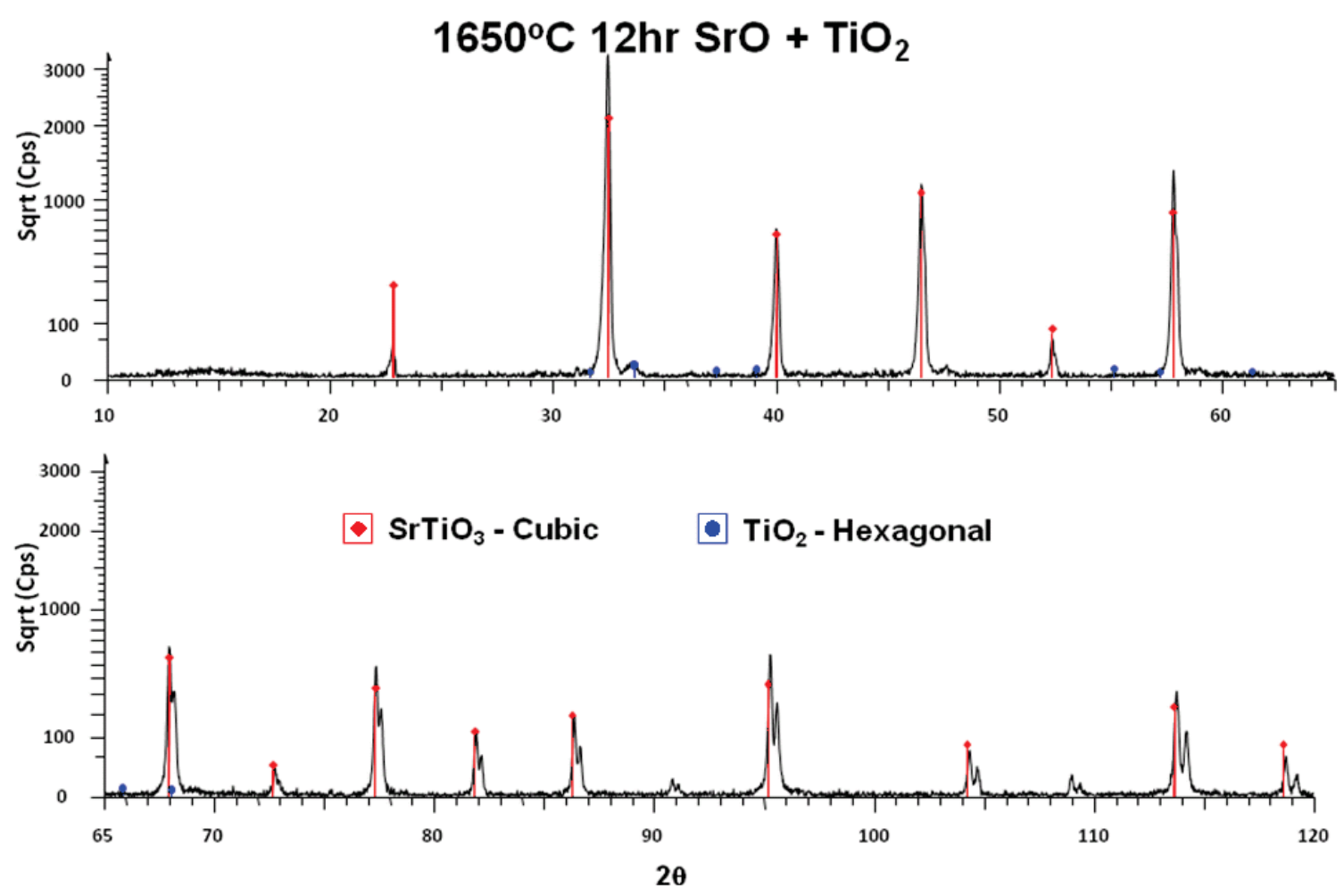

Figure 17b. XRD analysis of $\mathrm{SrO}+\mathrm{TiO}_{2}$ reaction at $1650^{\circ} \mathrm{C}$.

\subsection{9 $\mathrm{Ca}_{0.50} \mathrm{Sr}_{0.50} \mathrm{TiO}_{3}$ Synthesis}

The synthesis of $\mathrm{Ca}_{0.50} \mathrm{Sr}_{0.50} \mathrm{TiO}_{3}$ and other compositions will be performed later in $\mathrm{FY}-10$ when time is available. If time is not available, the work will be performed in FY-11.

\subsubsection{Synthesis of $\mathrm{CaZrTi}_{2} \mathrm{O}_{7}, \mathrm{Ca}_{1-\mathrm{x}} \mathrm{Sr}_{\mathrm{x}} \mathrm{Zr} \mathrm{Ti}_{2} \mathrm{O}_{7}$, and $\mathrm{SrZrTi}_{2} \mathrm{O}_{7}$}

The synthesis of $\mathrm{CaZrTi}_{2} \mathrm{O}_{7}, \mathrm{SrZrTi}_{2} \mathrm{O}_{7}$, and Sr-substituted $\mathrm{Ca}_{1-\mathrm{x}} \mathrm{Sr}_{\mathrm{x}} \mathrm{ZrTi}_{2} \mathrm{O}_{7}$ using mixed oxides in a hightemperature furnace followed the chemical equations listed below. In the strontium-substituted zirconolite, the mid composition of $\mathrm{Ca}_{0.50} \mathrm{Sr}_{0.50} \mathrm{ZrTi}_{2} \mathrm{O}_{7}$ was synthesized first for the study:

$\mathrm{CaO}+\mathrm{ZrO}_{2}+2 \mathrm{TiO}_{2} \rightarrow \mathrm{CaZrTi}_{2} \mathrm{O}_{7}$

$0.75 \mathrm{CaO}+0.25 \mathrm{SrO}+\mathrm{ZrO}_{2}+2 \mathrm{TiO}_{2} \rightarrow \mathrm{Ca}_{0.75} \mathrm{Sr}_{0.25} \mathrm{ZrTi}_{2} \mathrm{O}_{7}$

$0.50 \mathrm{CaO}+0.50 \mathrm{SrO}+\mathrm{ZrO}_{2}+2 \mathrm{TiO}_{2} \rightarrow \mathrm{Ca}_{0.50} \mathrm{Sr}_{0.50} \mathrm{ZrTi}_{2} \mathrm{O}_{7}$

$0.25 \mathrm{CaO}+0.75 \mathrm{SrO}+\mathrm{ZrO}_{2}+2 \mathrm{TiO}_{2} \rightarrow \mathrm{Ca}_{0.75} \mathrm{Sr}_{0.25} \mathrm{ZrTi}_{2} \mathrm{O}_{7}$

$\mathrm{SrO}+\mathrm{ZrO}_{2}+2 \mathrm{TiO}_{2} \rightarrow \mathrm{SrZrTi}_{2} \mathrm{O}_{7}$

The zirconolite, $\mathrm{CaZrTi}_{2} \mathrm{O}_{7}$, and the strontium fully substituted end member, $\mathrm{SrZrTi}_{2} \mathrm{O}_{7}$, were the first two compounds to be synthesized. The mixed oxides of these two targeted compounds were reacted at $1350^{\circ} \mathrm{C}$ for 16 hours and the products were analyzed by XRD. 
In the $\mathrm{CaO}+\mathrm{ZrO}_{2}+\mathrm{TiO}_{2}$ system, a low amount of $\mathrm{CaZrTi}_{2} \mathrm{O}_{7}$ was formed after the starting powders reacted for 13 hours at $1350^{\circ} \mathrm{C}$. A fairly noticeable amount of $\mathrm{CaTiO}_{3}$ was detected by XRD in the product. Significant amounts of tetragonal and FCC phase of $\mathrm{ZrO}_{2}$ were formed and a small amount of the starting monoclinic zirconia remained. The tetragonal and FCC structure of $\mathrm{ZrO}_{2}$ were stabilized when 3-8 $\mathrm{wt} \%$ of $\mathrm{CaO}$ dissolved into monoclinic $\mathrm{ZrO}_{2}$. A modest amount of $\mathrm{TiO}_{2}$ did not react. The low conversion of the starting powders to zirconolite was probably due to the very high melting temperature of $\mathrm{ZrO}_{2}$; the reaction temperature, $1350^{\circ} \mathrm{C}$, was not high enough for appreciable conversion of the starting oxides to the final product. Before the reaction, the starting powders were white. After 13 hours at $1350^{\circ} \mathrm{C}$, the color of the powder turned various shades of beige. The color of the interim product for $\mathrm{CaO}+\mathrm{TiO}_{2}, \mathrm{CaO}+\mathrm{ZrO}_{2}+\mathrm{TiO}_{2}, \mathrm{SrO}+\mathrm{TiO}_{2}$, and $\mathrm{SrO}+$ $\mathrm{ZrO}_{2}+\mathrm{TiO}_{2}$ after 13 hours of high-temperature reactions are shown in Figure 18. Based on XRD analysis this color change was indicative of different degrees of reaction in the powder system.

$\mathrm{The} \mathrm{CaO}+\mathrm{ZrO}_{2}+\mathrm{TiO}_{2}$ powder samples were further heated at $1650^{\circ} \mathrm{C}$ for another 16 hours. The powder samples melted through the alumina crucible and formed a solid melt with the alumina tray. The solid melt was cut from the crucible and an XRD analysis was performed. Alumina was observed as the primary product with very minor compositions of $\mathrm{CaZrTi}_{2} \mathrm{O}_{7}$ and $\mathrm{Al}_{0.18} \mathrm{Zr}_{0.82} \mathrm{O}_{1.91}$. The alumina crucible interfered with the $\mathrm{CaO}+\mathrm{TiO}_{2}$ and $\mathrm{CaO}+\mathrm{ZrO}_{2}+\mathrm{TiO}_{2}$ reactions at higher temperatures. These reactions were rerun with more inert crucibles.

In the $\mathrm{SrO}+\mathrm{ZrO}_{2}+\mathrm{TiO}_{2}$ system, a significant amount of $\mathrm{SrTiO}_{3}$ was formed. A small amount of $\mathrm{ZrTiO}_{4}$ was also formed and a moderate amount of $\mathrm{ZrO}_{2}$ remained. After the reaction at $1350^{\circ} \mathrm{C}$ for 13 hours, the color change for the $\mathrm{SrO}+\mathrm{ZrO}_{2}+\mathrm{TiO}_{2}$ powder system was significantly more than the $\mathrm{CaO}+\mathrm{ZrO}_{2}+$ $\mathrm{TiO}_{2}$ powder system. This indicated that under the same reaction conditions, the $\mathrm{SrO}+\mathrm{ZrO}{ }_{2}+\mathrm{TiO}_{2}$ powder system reacted much more than the $\mathrm{CaO}+\mathrm{ZrO}_{2}+\mathrm{TiO}_{2}$ powder system. This was confirmed by XRD analysis.

The $\mathrm{SrO}+\mathrm{ZrO}_{2}+\mathrm{TiO}_{2}$ powder system was further reacted at $1650^{\circ} \mathrm{C}$ for another 16 hours. Unlike the $\mathrm{CaO}+\mathrm{ZrO}_{2}+\mathrm{TiO}_{2}$ powder system, the $\mathrm{SrO}+\mathrm{ZrO}_{2}+\mathrm{TiO}_{2}$ powder system had little reaction with the alumina crucible. Besides a moderate amount of $\mathrm{SrTiO}_{3}$ and a very little amount of unreacted $\mathrm{ZrO}_{2}$, a major unidentified phase with high crystalline symmetry formed. These reactions would be repeated later with Pt crucibles.

\subsubsection{Second Synthesis of $\mathrm{CaZrTi}_{2} \mathrm{O}_{7}, \mathrm{Ca}_{0.5} \mathrm{Sr}_{0.5} \mathrm{Zr} \mathrm{Ti}_{2} \mathrm{O}_{7}$, and $\mathrm{SrZrTi}_{2} \mathrm{O}_{7}$}

The first synthesis of $\mathrm{CaZrTi}_{2} \mathrm{O}_{7}$ and $\mathrm{SrZrTi}_{2} \mathrm{O}_{7}$ were not very successful with alumina crucibles because of interference from the crucible material. A second synthesis attempt for $\mathrm{CaZrTi}{ }_{2} \mathrm{O}_{7}, \mathrm{Ca}_{0.5} \mathrm{Sr}_{0.5} \mathrm{Zr} \mathrm{Ti}_{2} \mathrm{O}_{7}$, and $\mathrm{SrZrTi}_{2} \mathrm{O}_{7}$ was carried out with more inert crucibles made with $\mathrm{AlN}-\mathrm{BN}-\mathrm{ZrO}_{2}$ composite material. However, this attempt was also unsuccessful due to sever interaction with the crucible material. At the initial reaction temperatures, $1350^{\circ} \mathrm{C}$, all three powder systems reacted with the $\mathrm{AlN}-\mathrm{BN}-\mathrm{ZrO}{ }_{2}$ crucible severely. The crucibles were destroyed by partial molten materials.

\subsubsection{Third Synthesis of $\mathrm{CaZrTi}_{2} \mathrm{O}_{7}, \mathrm{Ca}_{0.5} \mathrm{Sr}_{0.5} \mathrm{Zr} \mathrm{Ti}_{2} \mathrm{O}_{7}$, and $\mathrm{SrZrTi}_{2} \mathrm{O}_{7}$}

A third synthesis attempt for $\mathrm{CaZrTi}_{2} \mathrm{O}_{7}, \mathrm{Ca}_{0.5} \mathrm{Sr}_{0.5} \mathrm{ZrTi}_{2} \mathrm{O}_{7}$, and $\mathrm{SrZrTi}_{2} \mathrm{O}_{7}$ was carried out with $\mathrm{Pt}$ crucibles and the interference from the crucible material was eliminated. 


\subsubsection{3 $\mathrm{CaZrTi}_{2} \mathrm{O}_{7}$ Synthesis}

After reacting the mixed powder at $1350^{\circ} \mathrm{C}$ for 16 hours, XRD analysis showed that the reaction was incomplete. Besides zirconolites $\left(\mathrm{CaZrTi}_{2} \mathrm{O}_{7}\right)$, a significant amount of $\mathrm{CaTiO}_{3}$ was also formed. A fair amount of $\mathrm{TiO}_{2}$ and $\mathrm{ZrO}_{2}$ remain did not react. Zirconia has the highest melting temperature among all the reactants and the temperature was not high enough for a complete reaction. Figure 19 shows the result of the product after the 16 hours of reaction at $1350^{\circ} \mathrm{C}$.
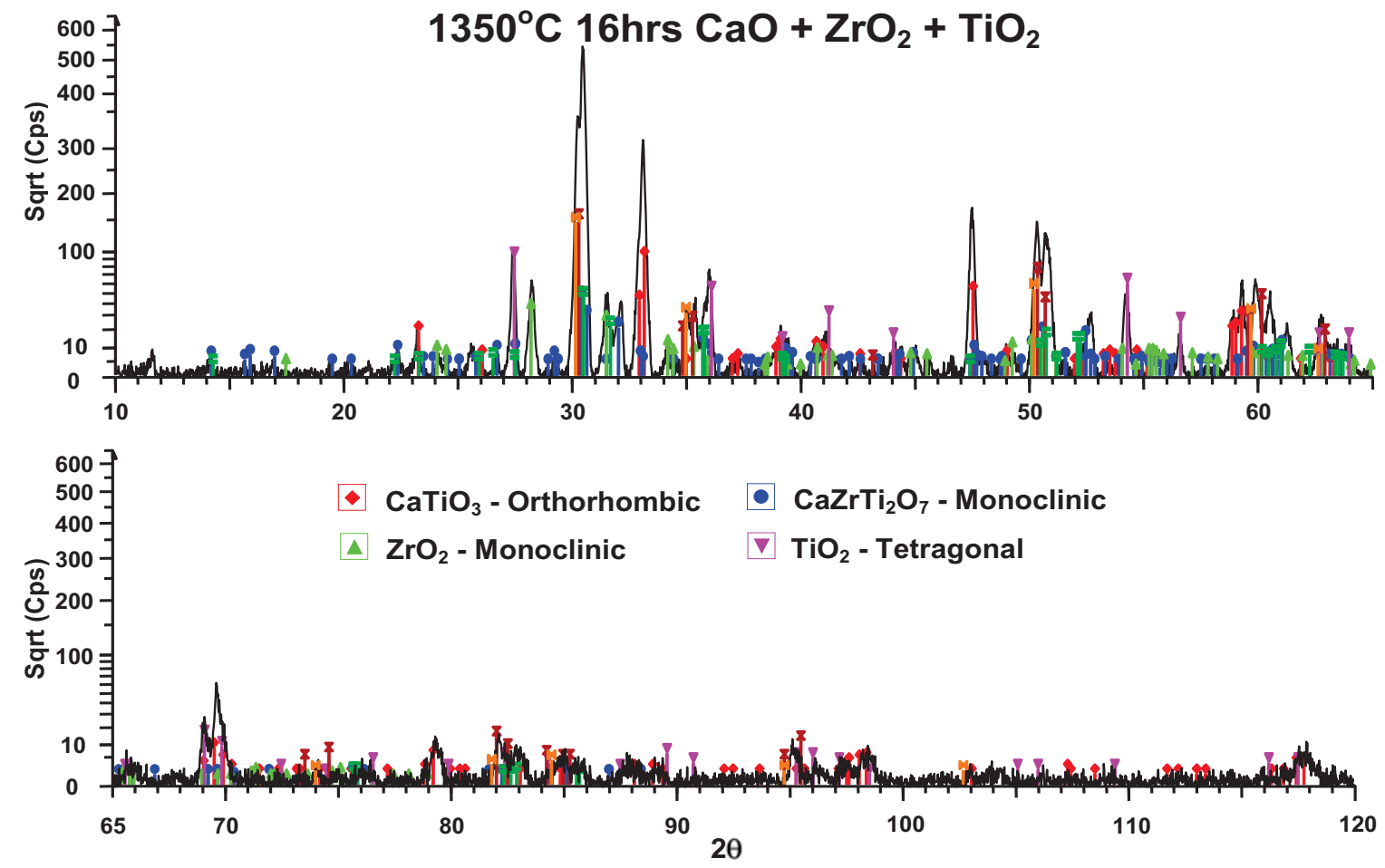

Figure 19. XRD result of the product after the 16 hours at $1350^{\circ} \mathrm{C}$.

The product was grounded up and reacted again at $1450^{\circ} \mathrm{C}$ for another 64 hours. XRD analysis showed the reaction was more complete and $\mathrm{CaTiO}_{3}$ and $\mathrm{TiO}_{2}$ disappeared from the product. Zirconolites $\left(\mathrm{CaZrTi}_{2} \mathrm{O}_{7}\right)$ was the major product, while a small amount of $\mathrm{ZrO}_{2}$ still remained. Figure 20 shows the result of the product after another 64 hours of reaction at $1450^{\circ} \mathrm{C}$. The product was reacted again at $1500^{\circ} \mathrm{C}$ for another 39 hours. XRD analysis showed the reaction was complete and a single phase of zirconolite $\left(\mathrm{CaZrTi}_{2} \mathrm{O}_{7}\right)$ was synthesized. Figure 21 shows the result of the product after the reaction at $1500^{\circ} \mathrm{C}$ for 39 additional hours. 


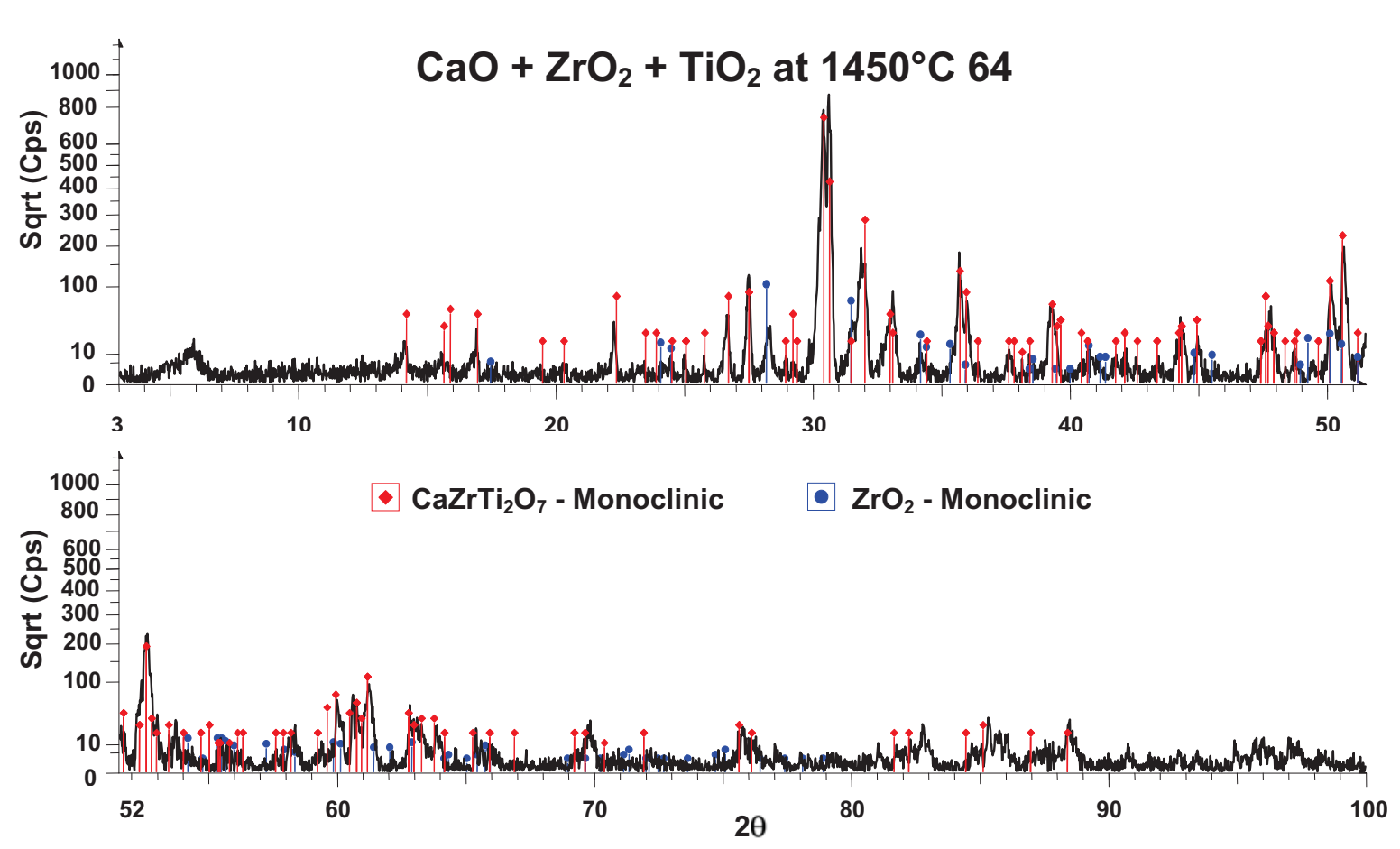

Figure 20. XRD result of the product after the 64 hours reaction at $1450^{\circ} \mathrm{C}$.
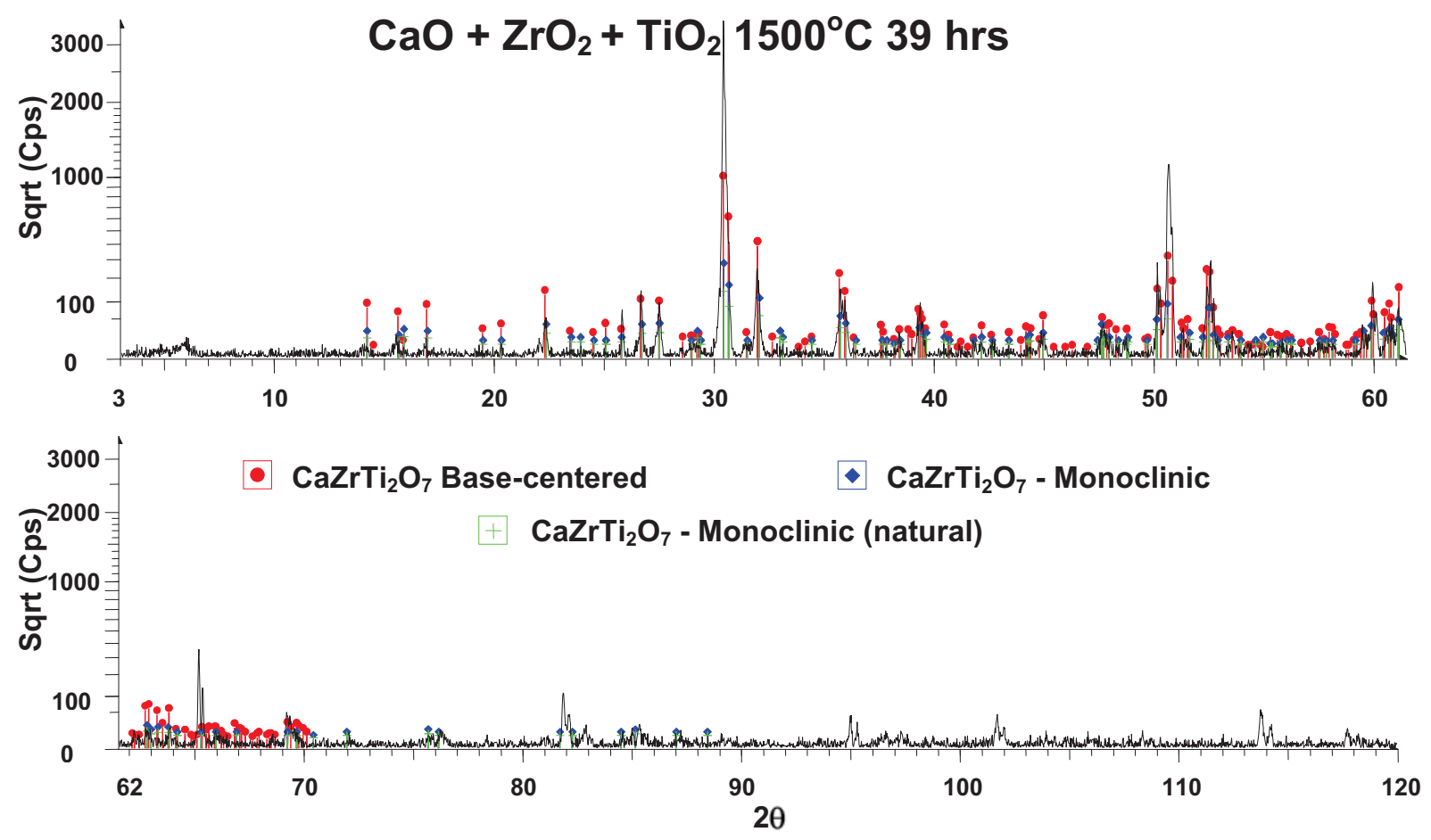

Figure 21. XRD result of the product after another 39 hours of reaction at $1500^{\circ} \mathrm{C}$.

\subsubsection{4 $\mathrm{SrZrTi}_{2} \mathrm{O}_{7}$ Synthesis}

In the synthesis of $\mathrm{SrZrTi}_{2} \mathrm{O}_{7}$, the mixed powder was initially reacted at $1350^{\circ} \mathrm{C}$ for 16 hours and then soaked at $1450^{\circ} \mathrm{C}$ for 64 hours. The total reaction time was 80 hours. XRD analysis of the product showed that a significant amount of $\mathrm{SrTiO}_{3}$ and $\mathrm{ZrTiO}_{4}$ formed. A minor amount of $\mathrm{ZrO}_{2}$ did not react. 
A second heating of the product was performed at $1500^{\circ} \mathrm{C}$ for another 39 hours. XRD analysis did not reveal significant changes in the phase compositions. $\mathrm{SrTiO}_{3}$ and $\mathrm{ZrTiO}_{4}$ were the major products with considerable amount of $\mathrm{ZrO}_{2}$ remaining. Figure 22 shows the XRD analyses of the reaction products for these two long-term runs. The analysis revealed that the products for these two runs were identical.

Another higher temperature run in the future is necessary.
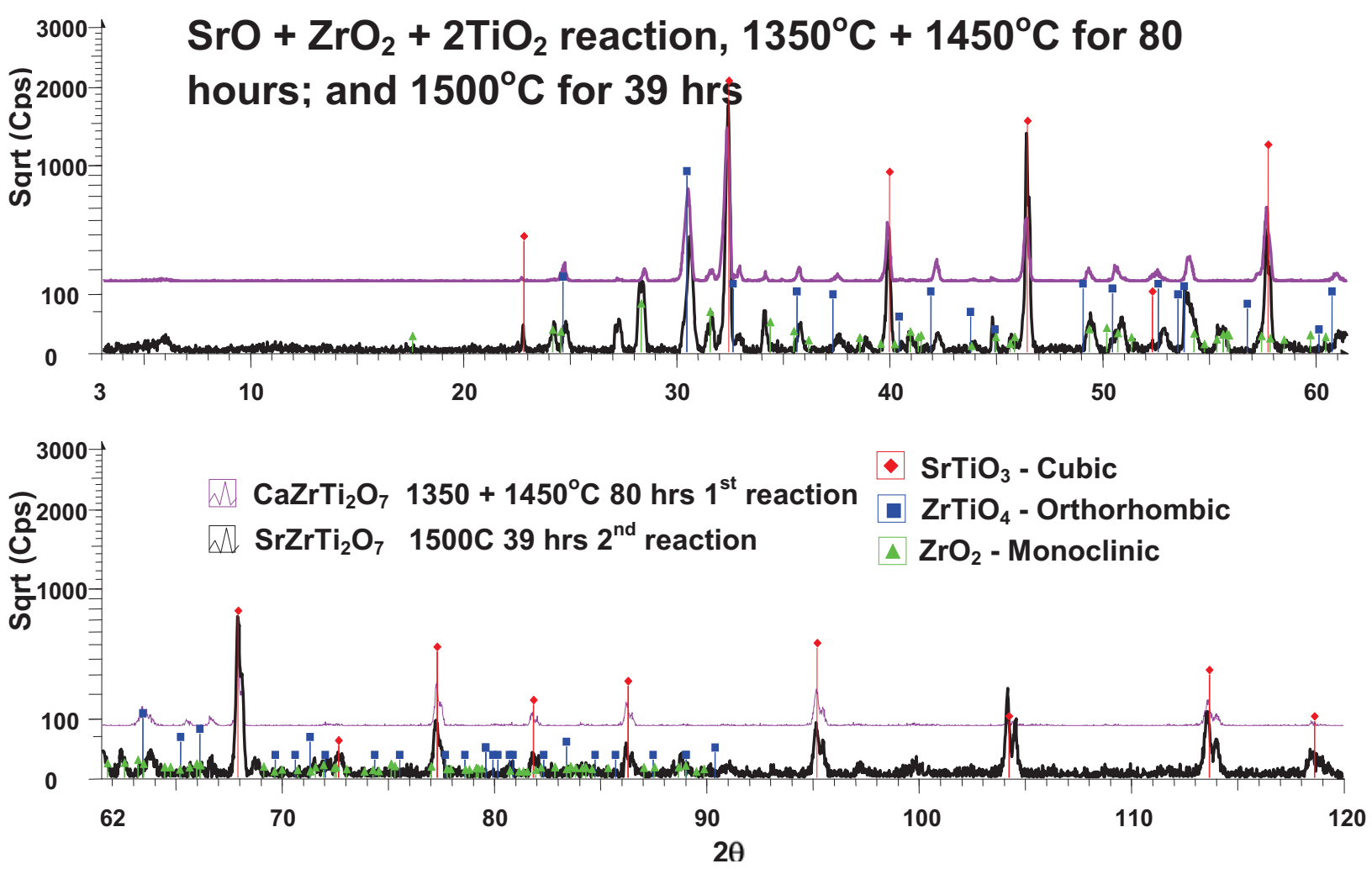

Figure 22. XRD result of the product after the 16 hours reaction at $1350^{\circ} \mathrm{C}$ and 64 hours at $1450^{\circ} \mathrm{C}$ (pink trace). XRD result of the product after additional 39 hours of reaction at $1500^{\circ} \mathrm{C}$ (black trace).

A third heating of the product at $1650^{\circ} \mathrm{C}$ for 60 hours was carried out to further the reaction. However, $\mathrm{XRD}$ analysis revealed that the phase compositions remained the same. $\mathrm{ZrTiO}_{4}$ showed a strong decrease in X-ray intensity, while $\mathrm{SrTiO}_{3}$ showed a significant increase in intensity. The unreacted $\mathrm{ZrO}_{2}$ remained the same. Figure 23 shows the XRD analysis of this run. At this stage it is not known whether $\mathrm{SrZrTi}_{2} \mathrm{O}_{7}$ exists. Perhaps the temperature required to form $\mathrm{SrZrTi}_{2} \mathrm{O}_{7}$ is higher than $1650^{\circ} \mathrm{C}$. To continue the research for $\mathrm{SrZrTi}_{2} \mathrm{O}_{7}$ a much higher temperature capability furnace must be available. Nevertheless, formation of $\mathrm{SrTiO}_{3}$ is highly desirable because the loading of strontium waste is $47.44 \mathrm{wt} \%$ in the crystalline host. Strontium loading in the hypothetical $\mathrm{SrZrTi}_{2} \mathrm{O}_{7}$ crystalline host is only $22.66 \mathrm{wt} \%$, a little bit less than half of the loading capacity of $\mathrm{SrTiO}_{3}$. 


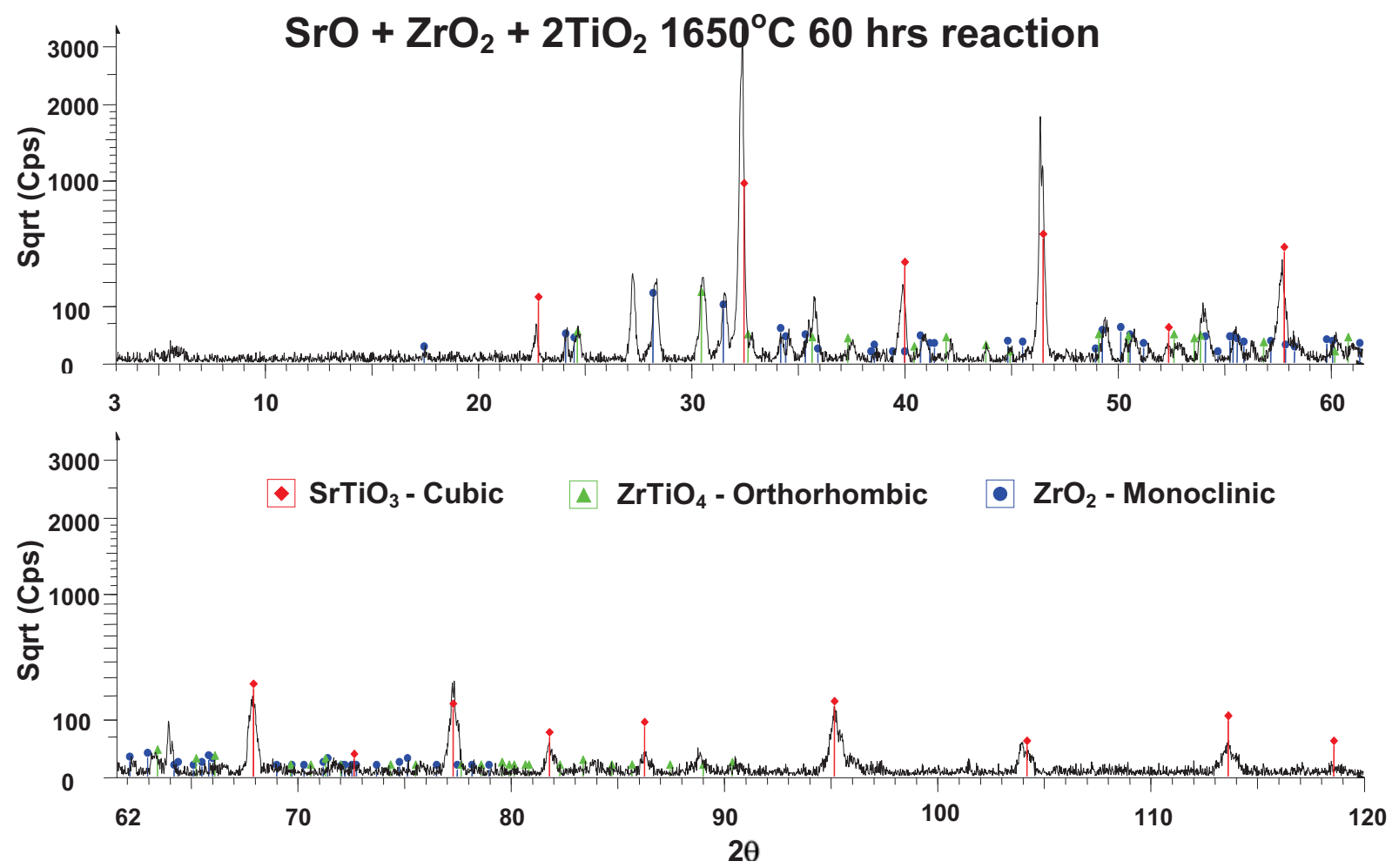

Figure 23. XRD result of the product after additional 39 hours of reaction at $1650^{\circ} \mathrm{C}$.

\subsubsection{5 $\mathrm{Ca}_{0.5} \mathrm{Sr}_{0.5} \mathrm{ZrTi}_{2} \mathrm{O}_{7}$ Synthesis}

In the synthesis of $\mathrm{Ca}_{0.5} \mathrm{Sr}_{0.5} \mathrm{Zr} \mathrm{Ti}_{2} \mathrm{O}_{7}$, the mixed powder was initially reacted at $1350^{\circ} \mathrm{C}$ for 16 hours and then soaked at $1450^{\circ} \mathrm{C}$ for another 64 hours. The total reaction time was 80 hours. XRD analysis of the product showed that $\mathrm{CaZrTi}_{2} \mathrm{O}_{7}$ and $\mathrm{Sr}_{2} \mathrm{TiO}_{4}$ were the major phases formed. A minor phase of $\mathrm{Sr}_{2} \mathrm{Ti}_{0.25} \mathrm{Zr}_{0.75} \mathrm{O}_{4}$ may also exist in the product. A second heating of the product was performed at $1500^{\circ} \mathrm{C}$ for another 39 hours. XRD analysis showed some recrystallization occurred and phase compositions remained similar. The $\mathrm{CaZrTi}_{2} \mathrm{O}_{7}$ diffraction profile became stronger and sharper while the $\mathrm{Sr}_{2} \mathrm{TiO}_{4}$ intensity remained unchanged. $\mathrm{The} \mathrm{Sr}_{2} \mathrm{Ti}_{0.25} \mathrm{Zr}_{0.75} \mathrm{O}_{4}$ phase remains possible. The Sr loading in $\mathrm{Sr}_{2} \mathrm{TiO}_{4}$ is 61.03 and $54.83 \mathrm{wt} \%$ in $\mathrm{Sr}_{2} \mathrm{Ti}_{0.25} \mathrm{Zr}_{0.75} \mathrm{O}_{4}$. With such a high $\mathrm{Sr}$ loading, these crystalline phases are highly desirable ceramic hosts for radioactive strontium. Figure 24 shows the XRD analysis of the product compositions for these two long-term runs.

A third heating of the product at $1650^{\circ} \mathrm{C}$ for 60 hours was carried out to study the reaction further. However, XRD analysis reveals that the phase composition had changed completely. $\mathrm{Sr}_{2} \mathrm{TiO}_{4}$ and $\mathrm{Sr}_{2} \mathrm{Ti}_{0.25} \mathrm{Zr}_{0.75} \mathrm{O}_{4}$ disappeared completely. This indicated that $\mathrm{Sr}_{2} \mathrm{TiO}_{4}$ and $\mathrm{Sr}_{2} \mathrm{Ti}_{0.25} \mathrm{Zr}_{0.75} \mathrm{O}_{4}$ were transitory phases and were stable below $1650^{\circ} \mathrm{C}$. In the synthesis of $\mathrm{SrTiO}_{3}$, the result also confirmed that $\mathrm{Sr}_{2} \mathrm{TiO}_{4}$ is not stable at $1650^{\circ} \mathrm{C}$. $\mathrm{CaZrTi}_{2} \mathrm{O}_{7}$ and $\mathrm{Ca}_{0.75} \mathrm{Sr}_{0.25} \mathrm{TiO}_{3}$ were the only phases present and the phase content was about equal. The $\mathrm{Sr}$ loading in $\mathrm{Ca}_{0.75} \mathrm{Sr}_{0.25} \mathrm{TiO}_{3}$ is only $14.82 \mathrm{wt} \%$ and is quite low compared to other $\mathrm{Sr}$ bearing phases identified before. Figure 25 shows the XRD analysis of this $1650^{\circ} \mathrm{C}$ run. Similar to $\mathrm{SrZrTi}_{2} \mathrm{O}_{7}$, the reaction temperature may need to be higher than $1650^{\circ} \mathrm{C}$ to synthesize the $\mathrm{Ca}_{0.5} \mathrm{Sr}_{0.5} \mathrm{ZrTi}_{2} \mathrm{O}_{7}$. 

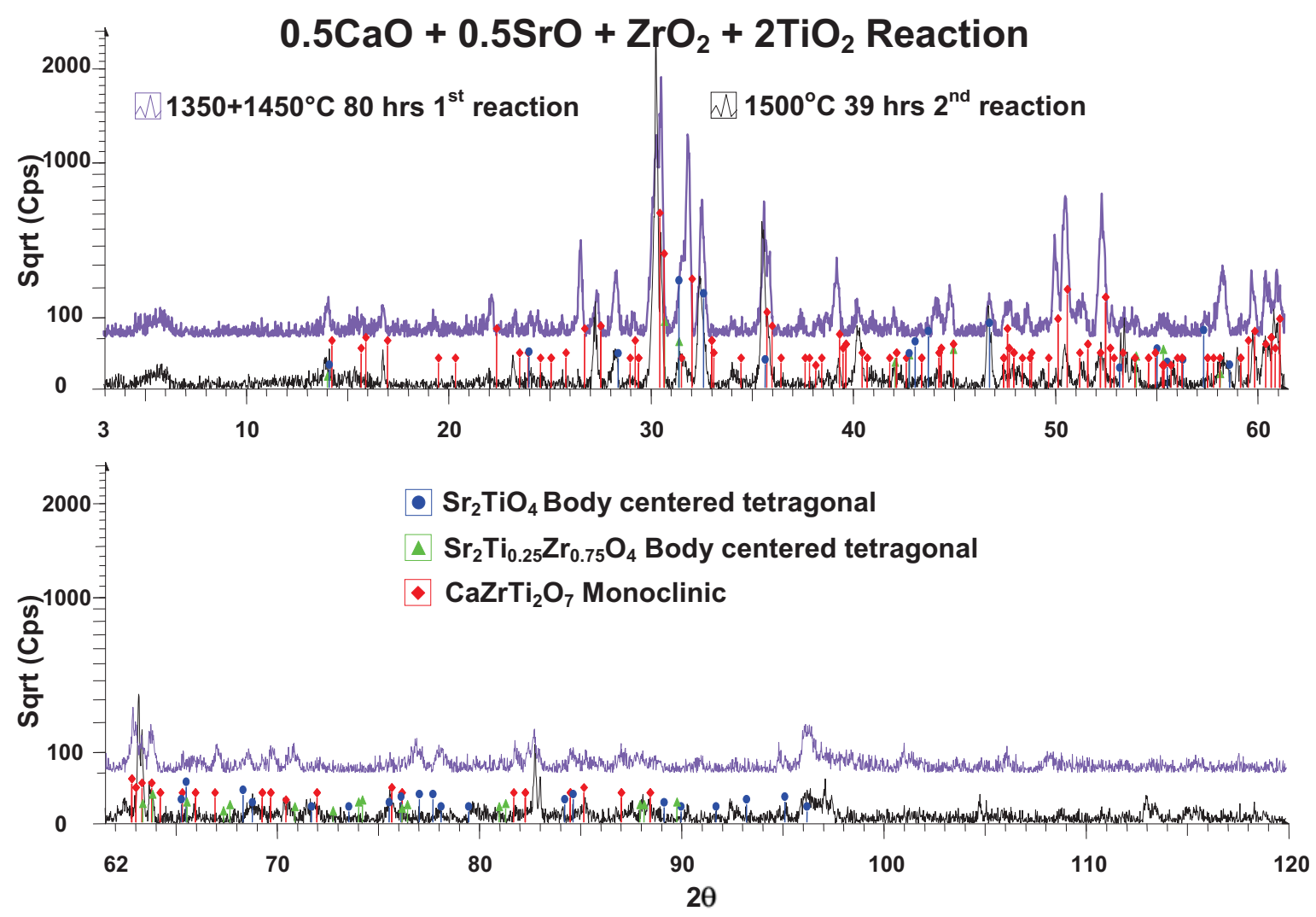

Figure 24. XRD result of the product after the 16 hours initial reaction at $1350^{\circ} \mathrm{C}$ and 64 hours soaking at $1450^{\circ} \mathrm{C}$ (purple trace). XRD result of the product after additional 39 hours of reaction at $1500^{\circ} \mathrm{C}$ (black trace).
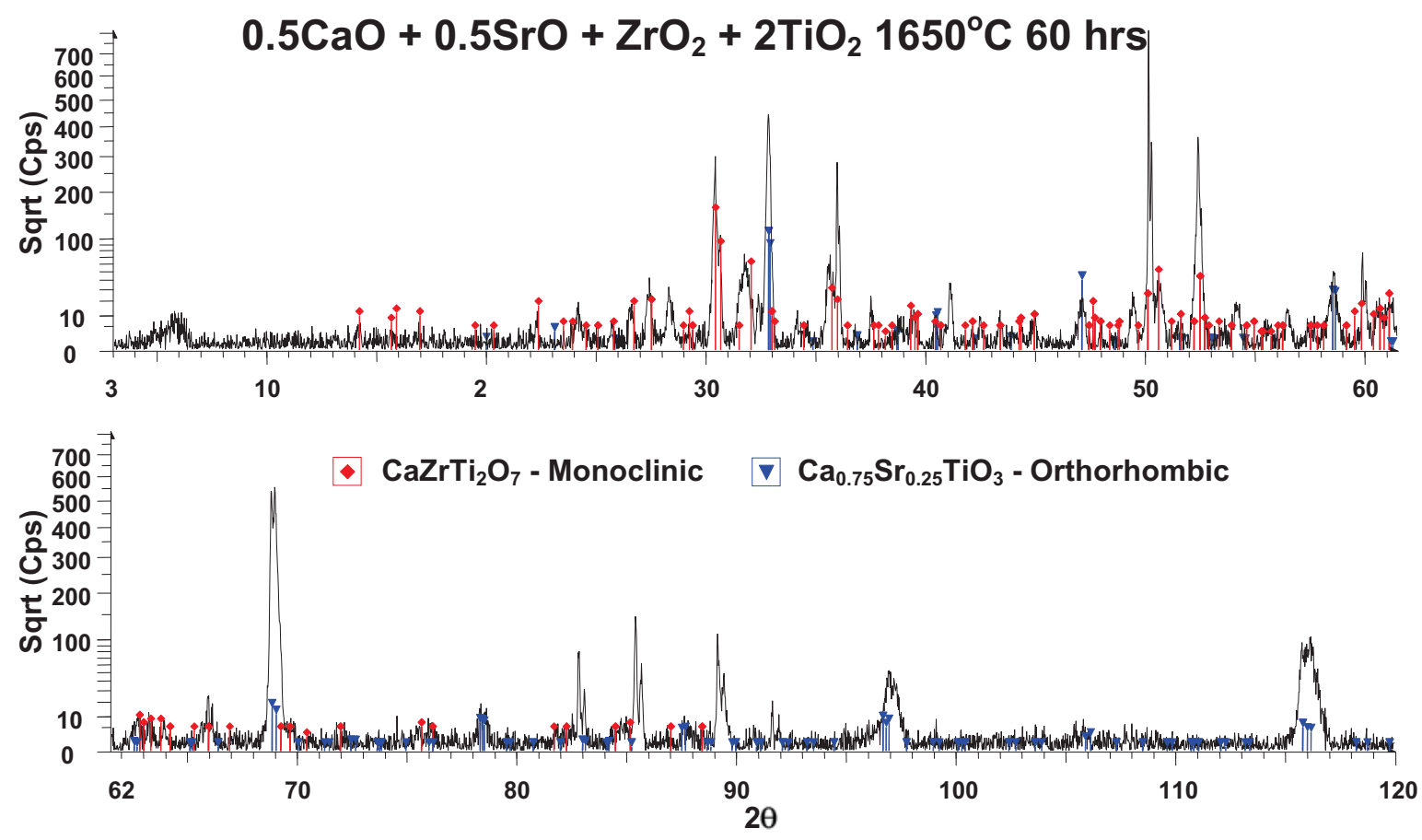

Figure 25. XRD result of the product after additional 39 hours of reaction at $1650^{\circ} \mathrm{C}$. 


\subsubsection{Synthesis of Lanthanide Substituted Crystalline Hosts}

The immobilization of lanthanide fission products in these ceramic host phases is part of the this year's study. Cerium oxide was chosen to represent the first of lanthanide fission products for substitution studies in spinel, perovskite, and zirconolite ceramic hosts. Cerium has +3 and +4 oxidation states and it may replace some of the trivalent or tetravalent host ions to produce the substitution ceramics, such as $\mathrm{MgAl}_{2-\mathrm{x}} \mathrm{Ce}_{\mathrm{x}} \mathrm{O}_{4}, \mathrm{CaTi}_{1-\mathrm{x}} \mathrm{Ce}_{\mathrm{x}} \mathrm{O}_{3}, \mathrm{CaZr}_{1-\mathrm{x}} \mathrm{Ce}_{\mathrm{x}} \mathrm{Ti}_{2} \mathrm{O}_{7}$, and $\mathrm{CaZrTi}_{2-\mathrm{x}} \mathrm{Ce}_{\mathrm{x}} \mathrm{O}_{7}$. The first three systems studied this year were $\mathrm{MgAl}_{1.5} \mathrm{Ce}_{0.5} \mathrm{O}_{4}, \mathrm{CaTi}_{0.5} \mathrm{Ce}_{0.5} \mathrm{O}_{3}$, and $\mathrm{CaZr}_{0.5} \mathrm{Ce}_{0.5} \mathrm{Ti}_{2} \mathrm{O}_{7}$. The reactions to synthesize these substitution crystalline phases are listed below:

$\mathrm{MgO}+(0.75) \mathrm{Al}_{2} \mathrm{O}_{3}+0.5 \mathrm{CeO}_{2} \rightarrow \mathrm{MgAl}_{1.5} \mathrm{Ce}_{0.5} \mathrm{O}_{4+\mathrm{x}}$

$\mathrm{CaO}+0.5 \mathrm{TiO}_{2}+0.5 \mathrm{CeO}_{2} \rightarrow \mathrm{CaTi}_{0.5} \mathrm{Ce} 0{ }_{5} \mathrm{O}_{3}$

$\mathrm{CaO}+0.5 \mathrm{ZrO}_{2}+0.5 \mathrm{CeO}_{2}+2 \mathrm{TiO}_{2} \rightarrow \mathrm{CaZr}_{0.50} \mathrm{Ce}_{0.50} \mathrm{Ti}_{2} \mathrm{O}_{7}$.

All the synthesis reactions were carried out with graphfoil lined alumina crucibles. The Pt crucibles used for the last series of runs were coated with solid residues that could not be completely removed from the crucibles. Mechanical cleaning did not remove all the solid mass from the Pt surface. These Pt crucibles will not be used for further synthesis work until all contaminants are completely removed from the crucibles.

\subsubsection{7 $\mathrm{MgAl}_{1.5} \mathrm{Ce}_{0.5} \mathrm{O}_{4.25}$ Synthesis}

$\mathrm{MgO}, \mathrm{Al}_{2} \mathrm{O}_{3}$, and $\mathrm{CeO}_{2}$ in the right ratios were well mixed and reacted in a graphfoil lined alumina crucible for 144 hours at $1525^{\circ} \mathrm{C}$. The product mass was brown and didn't seem homogeneous. The solid was granulated and analyzed by XRD. Figure 26 shows the XRD analysis of the product for this reaction. XRD revealed the three crystalline phases of the $\mathrm{MgAl}_{2} \mathrm{O}_{4}$ and unreacted $\mathrm{MgO}$ and $\mathrm{CeO}_{2}$. Since alumina and magnesium oxide was not in 1:1 mole relationship, the excess amount of $\mathrm{MgO}$ would remain unreacted if the compound $\mathrm{MgAl}_{1.5} \mathrm{Ce}_{0.5} \mathrm{O}_{4.25}$ does not exist. This was the first time in the work that a very well formed phase of $\mathrm{Al}_{2} \mathrm{O}_{4}$ appeared in the product. It was possible that the reaction time was sufficiently long and the temperature was high enough to form this phase. In follow-up work to be conducted next fiscal year, the product will need to react at temperatures much higher than $1525^{\circ} \mathrm{C}$ to see if the compound, $\mathrm{MgAl}_{1.5} \mathrm{Ce}_{0.5} \mathrm{O}_{4.25}$, will form. 

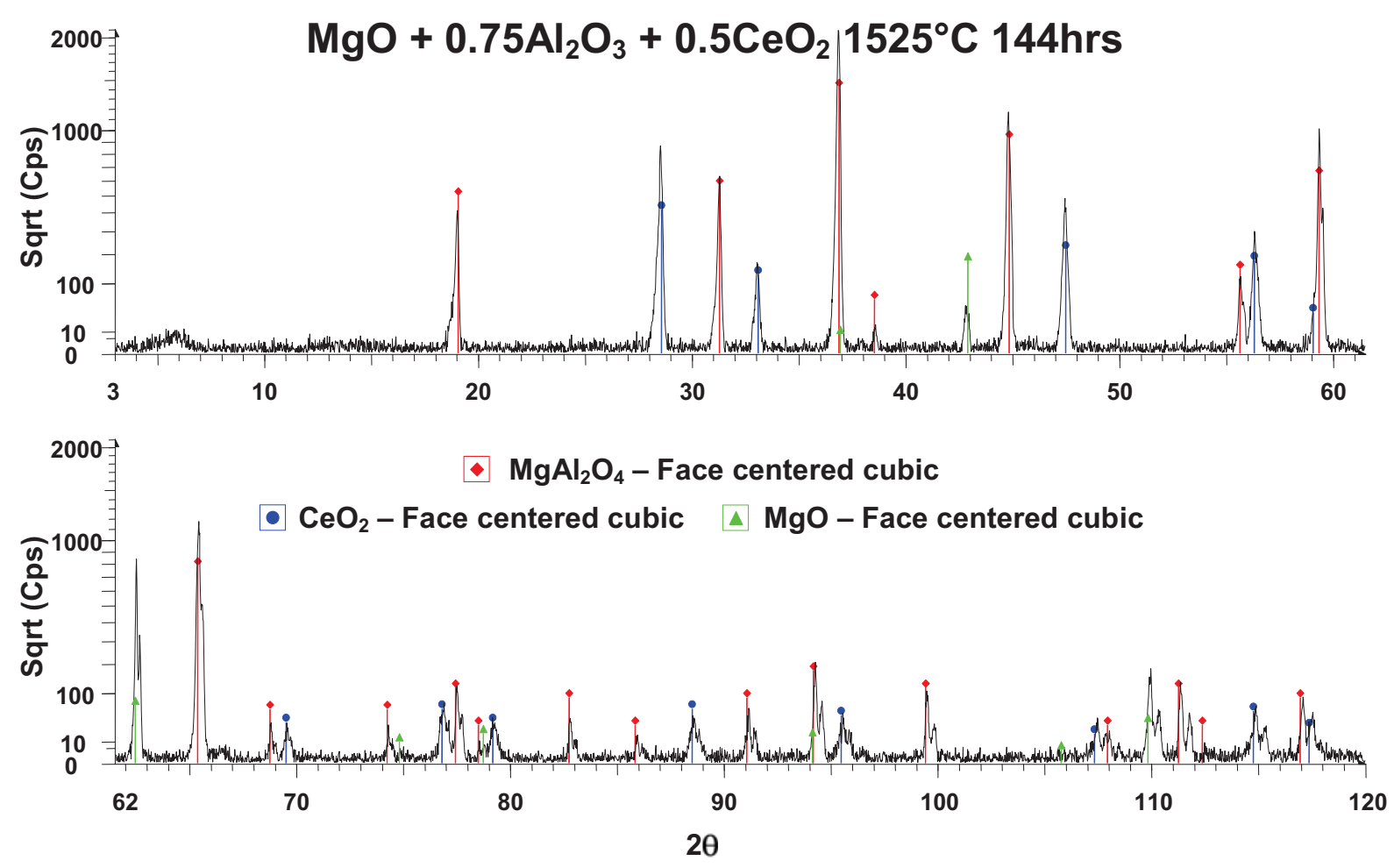

Figure 26. XRD analysis of the $\mathrm{MgO}+0.75 \mathrm{Al}_{2} \mathrm{O}_{3}+0.5 \mathrm{CeO}_{2}$ reaction product.

\subsubsection{8 $\mathrm{CaTi}_{0.5} \mathrm{CeO}_{.5} \mathrm{O}_{3}$ Synthesis}

$\mathrm{CaO}, \mathrm{TiO}_{2}$, and $\mathrm{CeO}_{2}$ in the right ratios were well mixed and reacted in a graphfoil lined alumina crucible for 144 hours at $1525^{\circ} \mathrm{C}$. The product was peach/pink and didn't seem homogeneous. The solid mass was granulated and analyzed by XRD. Figure 27 shows the XRD analysis of the product for this reaction. XRD revealed two titanates, $\mathrm{CaTiO}_{3}$ and $\mathrm{Ca}_{4} \mathrm{Ti}_{3} \mathrm{O}_{10}$, a calcium ceriate, $\mathrm{Ca}_{0.1} \mathrm{Ce}_{0.9} \mathrm{O}_{1.9}$, and $\mathrm{CeO}_{2}$ in the product. There are two unidentified peaks between 30 and 32 degree $2 \theta$. These crystalline phases will need to further react at much higher temperatures to see if $\mathrm{CaTi}_{0.5} \mathrm{Ce}_{0.5} \mathrm{O}_{3}$ will form. The ion size of $\mathrm{Ca}^{2+}$ and $\mathrm{Ce}^{4+}$ differs only by $1.98 \%$ and higher calcium ceriates could exist. In terms of Ce loading, binary ceriates can immobilize more Ce than tertiary ceriates. For example, Ce loading in $\mathrm{Ca}_{0.1} \mathrm{Ce}_{0.9} \mathrm{O}_{1.9}$ is $78.56 \mathrm{wt} \%$, while Ce loading in $\mathrm{CaTi}_{0.5} \mathrm{Ce}_{0.5} \mathrm{O}_{3}$ is only $38.49 \mathrm{wt} \%$, and a little less than half the loading in $\mathrm{Ca}_{0.1} \mathrm{Ce}_{0.9} \mathrm{O}_{1.9}$. 


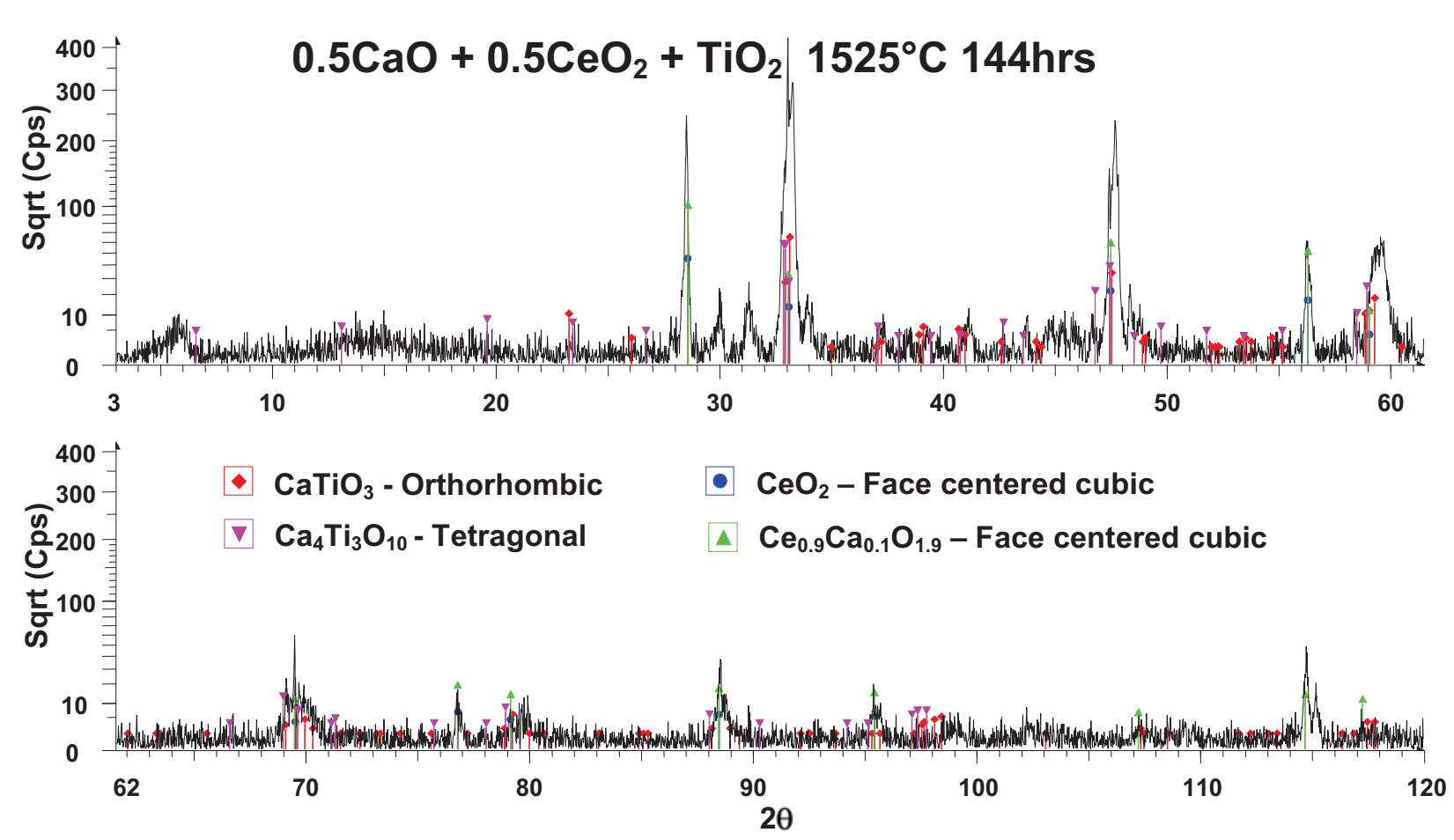

Figure 27. $\mathrm{XRD}$ analysis of the $0.5 \mathrm{CaO}+0.5 \mathrm{CeO}_{2}+\mathrm{TiO}_{2}$ reaction product.

\subsubsection{9 $\mathrm{CaZr}_{0.50} \mathrm{Ce}_{0.50} \mathrm{Ti}_{2} \mathrm{O}_{7}$ Synthesis}

$\mathrm{CaO}, \mathrm{TiO}_{2}, \mathrm{ZrO}_{2}$, and $\mathrm{CeO}_{2}$ in the right ratios were well mixed and reacted in a graphfoil lined alumina crucible for 144 hours at $1525^{\circ} \mathrm{C}$. The reaction from this experiment was very different from the reactions of the other two. The powder charge seemed to melt completely and wet the entire alumina crucible both inside and outside to form a smooth chocolate-brown coating. The molten material also left a smooth layer at the bottom of the crucible, which was cut off and examined by XRD. The result of the XRD is shown in Figure 28. Alumina is pretty much the exclusive phase present. However, other residue phases (such as $\mathrm{CaZrTi}_{2} \mathrm{O}_{7}, \mathrm{Al}_{0.08} \mathrm{Zr}_{0.92} \mathrm{O}_{1.96}, \mathrm{Ce}_{2} \mathrm{O}_{3}$, and $\mathrm{CeO}_{2}$ ) were also matched. Again, this reaction was interfered by the alumina crucible. This reaction must be rerun with a Pt crucible next fiscal year to avoid alumina interference. 

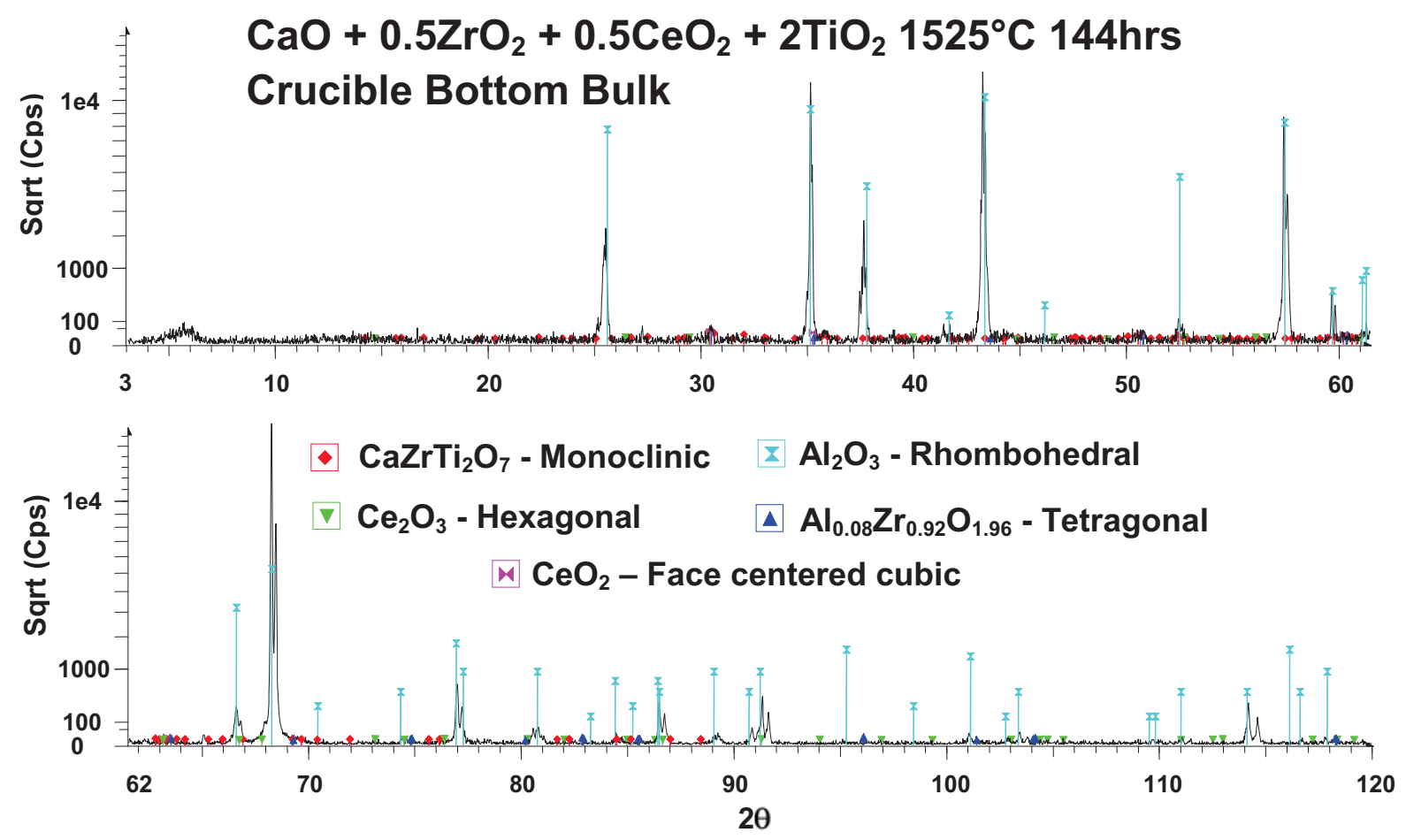

Figure 28. XRD analysis of the $\mathrm{CaO}+0.5 \mathrm{ZrO}_{2}+0.5 \mathrm{CeO}_{2}+2 \mathrm{TiO}_{2}$ reaction product. 


\section{CONCLUSION}

Several crystalline hosts were synthesized and proposed for fission products immobilization. A recent FY-10 study concentrated on strontium substitution into spinels $\left(\mathrm{MgAl}_{2} \mathrm{O}_{4}\right)$, perovskite $\left(\mathrm{CaTiO}_{3}\right)$, and zirconolite $\left(\mathrm{CaZrTi}_{2} \mathrm{O}_{7}\right)$. Strontium cannot substitute into $\mathrm{Mg}^{2+}$ sites in the spinel structure because the $\mathrm{Sr}^{2+}$ ion is much larger than the $\mathrm{Mg}^{2+}$ ions. This research found that $\mathrm{CaAl}_{2} \mathrm{O}_{4}$ is a suitable alternative for $\mathrm{Sr}$ immobilization because $\mathrm{Sr}^{2+}$ is only $14 \%$ larger than $\mathrm{Ca}^{2+}$. Both $\mathrm{CaAl}_{2} \mathrm{O}_{4}$ and $\mathrm{SrAl}_{2} \mathrm{O}_{4}$ have identical crystalline structure and their unit cell dimensions are quite similar to each other. Both systems also have higher members that are analogue to each other and their crystalline structures are identical. A single phase of $\mathrm{Ca}_{0.5} \mathrm{Sr}_{0.5} \mathrm{Al}_{2} \mathrm{O}_{4}$ may have been synthesized and more analysis of this material is necessary to confirm the composition. The $\mathrm{CaTiO}_{3}$ and $\mathrm{SrTiO}_{3}$ have been successfully synthesized as a single phase product. $\mathrm{CaZrTi}_{2} \mathrm{O}_{7}$ was also successfully synthesized. However, $\mathrm{SrZrTi}{ }_{2} \mathrm{O}_{7}$ and $\mathrm{Ca}_{0.5} \mathrm{Sr}_{0.5} \mathrm{ZrTi}_{2} \mathrm{O}_{7}$ have not been successfully synthesized yet. Higher temperature synthesis work will need to continue for these compositions. Several crystalline phases identified have high Sr loading and most are stable at temperatures $\leq 1650^{\circ} \mathrm{C}$. These crystalline aluminate and titanate hosts listed in Table 1 are suitable for $\mathrm{Sr}$ immobilization. More work need to be performed in this area in FY-11.

Table 1. Crystalline aluminate and titanate hosts suitable for immobilization.

\begin{tabular}{|l|l|l|l|l|l|l|}
\hline Aluminates & $\mathbf{S r A l}_{\mathbf{1 2}} \mathbf{O}_{\mathbf{1 9}}$ & $\mathbf{M g S r A l}_{\mathbf{1 0}} \mathbf{O}_{\mathbf{1 7}}$ & $\mathbf{S r}_{\mathbf{3}} \mathbf{A l}_{\mathbf{3 2}} \mathbf{O}_{\mathbf{5 1}}$ & \multicolumn{1}{|c|}{$\mathbf{S r A l}_{\mathbf{2}} \mathbf{O}_{\mathbf{4}}$} & $\mathbf{S r}_{\mathbf{1 2}} \mathbf{A l}_{\mathbf{1 4}} \mathbf{O}_{\mathbf{3 3}}$ & $\mathbf{S r}_{\mathbf{3}} \mathbf{A l}_{\mathbf{2}} \mathbf{O}_{\mathbf{6}}$ \\
\hline Sr loading & $12.25 \%$ & $13.40 \%$ & $13.53 \%$ & $42.62 \%$ & $53.72 \%$ & $63.67 \%$ \\
\hline Titanates & $\mathrm{SrTiO}_{3}$ & $\mathrm{SrTiO}_{2.72}$ & $\mathrm{Sr}_{2} \mathrm{TiO}_{4}$ & $\mathrm{Ca}_{0.75} \mathrm{Sr}_{0.25} \mathrm{TiO}_{3}$ & $\mathrm{Sr}_{2} \mathrm{Ti}_{0.25} \mathrm{Zr}_{0.75} \mathrm{O}_{4}$ \\
\hline Sr loading & $47.74 \%$ & $48.94 \%$ & $61.03 \%$ & $14.82 \%$ & $54.83 \%$ & \\
\hline
\end{tabular}

In the lanthanide fission products immobilization study, the synthesis of cerium-substituted crystalline hosts of $\mathrm{MgAl}_{1.5} \mathrm{Ce}_{0.5} \mathrm{O}_{4.25}, \mathrm{CaTi}_{0.5} \mathrm{Ce}{ }_{.5} \mathrm{O}_{3}$, and $\mathrm{CaZr}_{0.50} \mathrm{Ce}_{0.50} \mathrm{Ti}_{2} \mathrm{O}_{7}$ were attempted. No such substitutions were observed in the products synthesized so far. Only one binary crystalline phase, $\mathrm{Ca}_{0.1} \mathrm{Ce}_{0.9} \mathrm{O}_{1.9}$, was identified with very high Ce loading $(78.56 \%)$. Much higher temperature reactions are needed to investigate the feasibility to form these crystalline phases in FY-11. Substitution of lanthanides and strontium simultaneously into these crystalline phases also need to be investigated in out years. 